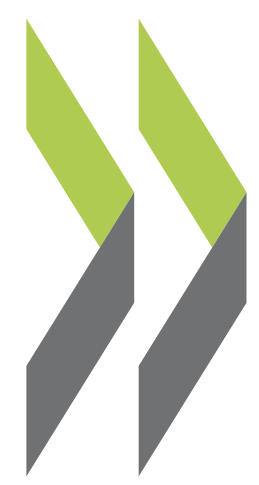

OECD Economics Department Working Papers No. 878

Policies to Rebalance Housing Markets in New

Calista Cheung Zealand 


\section{Unclassified}

ECO/WKP(2011)47

Organisation de Coopération et de Développement Économiques

Organisation for Economic Co-operation and Development

01-Jul-2011

ECONOMICS DEPARTMENT

English - Or. English

POLICIES TO REBALANCE HOUSING MARKETS IN NEW ZEALAND

ECONOMICS DEPARTMENT WORKING PAPER No. 878

By Calista Cheung

All OECD Economics Department Working Papers are available on the OECD Intranet website at www.oecd.org/eco/workingpapers

JT03304778

Document complet disponible sur OLIS dans son format d'origine

Complete document available on OLIS in its original format 


\section{ABSTRACT/RESUME}

\section{Policies to rebalance housing markets in New Zealand}

A considerable housing boom has been a key feature of persistently large saving-investment imbalances in New Zealand over the past decade. Wealth is concentrated to a greater extent in property compared to most other OECD countries, leaving households and the banking system heavily exposed to a correction in land and housing markets. Supply rigidities and tax incentives that bias savings decisions towards property investment have amplified the increase in house prices, widening wealth inequalities in the form of larger homes for those who can afford them, but deteriorating affordability for the rest of the population. Substantial distortions via tax planning have been evident in rental property markets. Although the 2010-11 budget introduced measures to reduce some of these distortions, further reforms are needed to remove the significant tax bias favouring housing. The economic downturn has increased financial pressures on the social housing sector, with a shortage of public dwellings in areas of high demand. Regional supply constraints reflect inefficient land-use policies and long delays arising from an overly complex urban planning system. The adoption of spatial planning frameworks is a positive step forward, but they should include pricing mechanisms for land and road use that are aligned with broader policy objectives. This Working Paper relates to the 2011 OECD Economic Review of New Zealand (www.oecd.org/eco/surveys/NewZealand).

JEL classification codes: E21, E32, H21, H23, H24, H71, R21,R31, R38, R52

Keywords: housing markets; house prices; housing policies; New Zealand; household wealth; household saving; housing taxation; capital gains tax; property tax; social housing; land-use planning; urban planning; land prices

$$
* * * * * * *
$$

\section{Mesures pour rééquilibrer les marchés du logement en Nouvelle-Zélande}

Au cours des dix dernières années, le boum spectaculaire du marché du logement a été l'une des principales caractéristiques des déséquilibres importants et persistants entre l'épargne et l'investissement en Nouvelle-Zélande. La richesse est beaucoup plus concentrée dans l'immobilier que dans la plupart des autres pays de l'OCDE, ce qui expose massivement les ménages et le système bancaire à un risque de correction du marché foncier et du marché du logement. Les rigidités du côté de l'offre et les mesures d'incitation fiscale qui influencent les décisions d'épargne au profit des investissements immobiliers ont amplifié la hausse des prix des logements, creusant les inégalités de richesse qui se matérialisent par des logements plus vastes pour ceux qui peuvent se les payer alors que l'accessibilité financière au logement se détériore pour le reste de la population. Des distorsions substantielles imputables à la fiscalité sont devenues visibles sur les marchés de l'immobilier locatif. Bien que le budget 2010-11 ait introduit des mesures pour réduire certaines de ces distorsions, de nouvelles réformes sont nécessaires pour supprimer les biais fiscaux significatifs qui favorisent le logement. Le ralentissement économique a accru les pressions financières sur le secteur du logement social, entraînant une pénurie de logements publics dans des zones où la demande est forte. Le caractère limité de l'offre régionale reflète des politiques d'aménagement du territoire inefficientes et des retards importants imputables à un système de planification urbaine exagérément complexe. L'adoption de cadres d'aménagement du territoire constitue un pas en avant positif, mais cet encadrement devrait inclure des mécanismes tarifaires pour l'aménagement du territoire et des infrastructures routières alignés sur des objectifs politiques plus larges. Ce Document de travail se rapporte à l'Étude économique de l'OCDE de la Nouvelle-Zélande 2011 (www.oecd.org/eco/etudes/Nouvelle-Zélande).

Classification JEL : E21, E32, H21, H23, H24, H71, R21, R31, R38, R52

Mots clefs : marchés du logement ; prix des logements ; politiques du logement ; Nouvelle-Zélande ; patrimoine des ménages ; épargne des ménages ; fiscalité de l'immobilier ; impôt sur les plus-values ; impôt sur la propriété immobilière ; logement social ; planification de l'occupation des sols ; planification urbaine ; prix du terrain

Copyright $\odot$ OECD, 2011. All rights reserved. Application for permission to reproduce or translate all, or part of, this material should be made to: Head of Publications Service, OECD, 2 rue André-Pascal, 75775 PARIS CEDEX 16, France. 


\section{Table of contents}

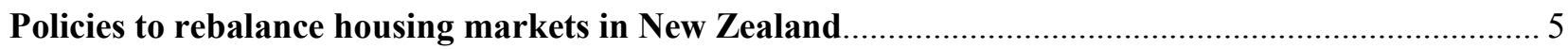

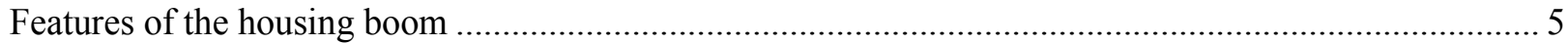

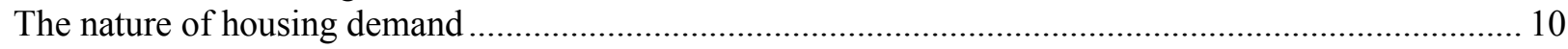

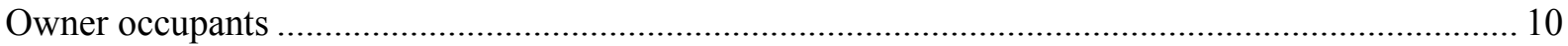

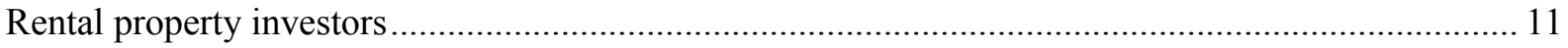

Are households' portfolios too concentrated in housing? ................................................................... 12

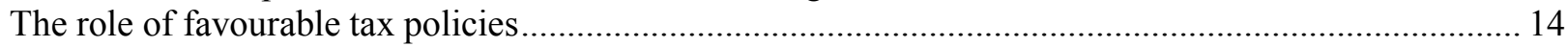

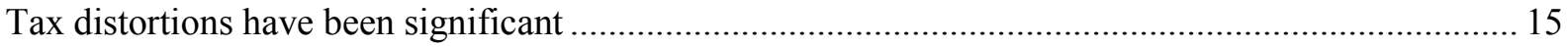

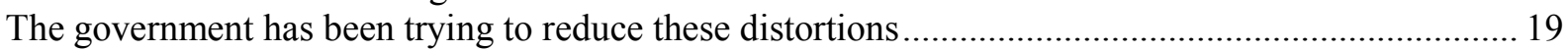

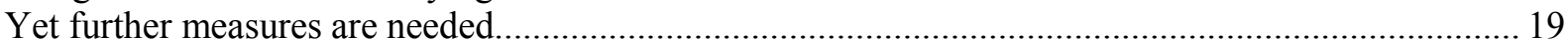

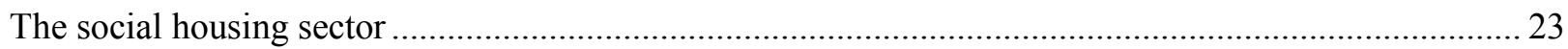

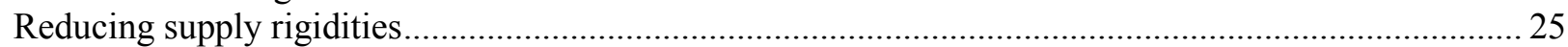

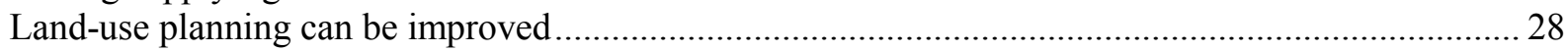

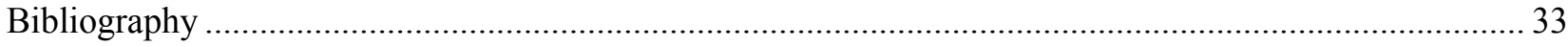

Annex Housing-related taxation: interest deductibility, imputed rent and capital gains tax ...................... 38

\section{Boxes}

1. The effect of New Zealand's tax system on housing values ..................................................... 17

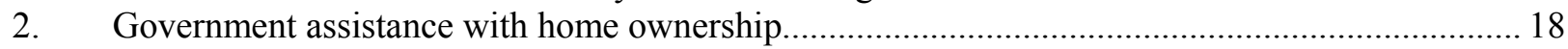

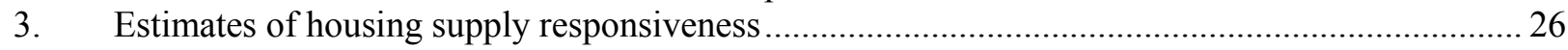

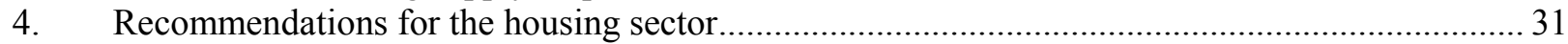

\section{Tables}

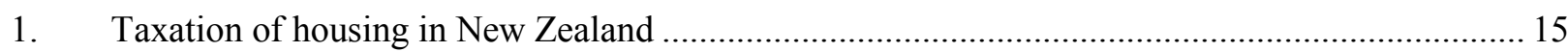

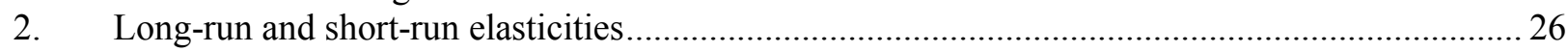

\section{Figures}

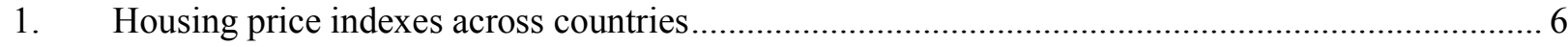

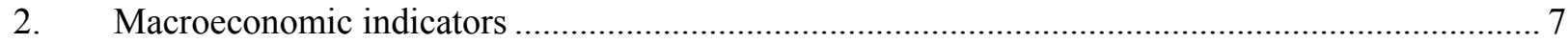

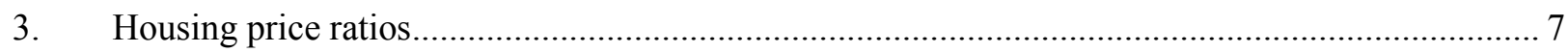

4. Lending by financial institutions to housing, business and agriculture ........................................ 8

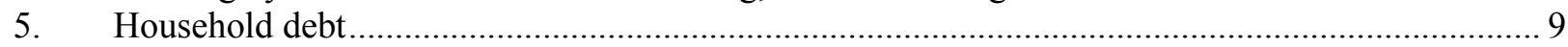

6. Household indebtedness across income quintiles....................................................................... 9

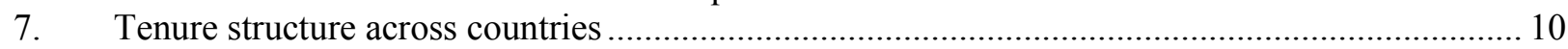




\section{ECO/WKP(2011)47}

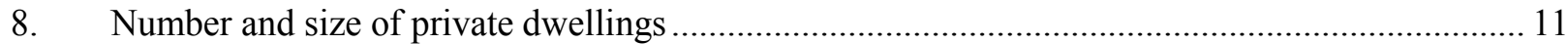

9. Financial and non-financial assets as a percentage of net disposable income.............................. 12

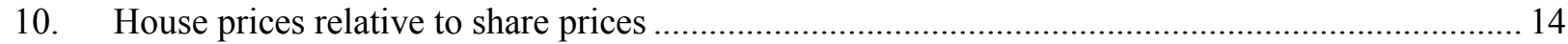

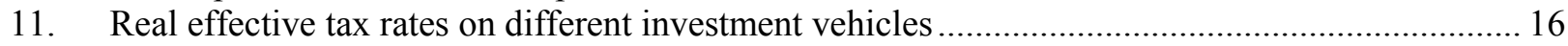

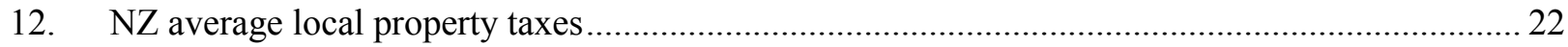

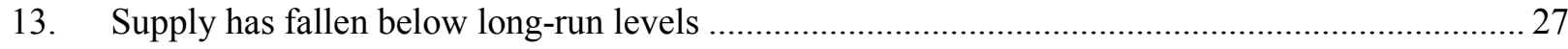

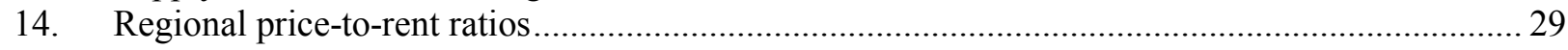


ECO/WKP(2011)47

\title{
Policies to rebalance housing markets in New Zealand
}

\author{
By Calista Cheung ${ }^{1}$
}

Similar to many other OECD countries, New Zealand experienced a sharp boom in housing markets during the past decade, with important implications for overall economic performance as well as for social outcomes. Swelling household mortgage and other debt has been funded largely from abroad, exacerbating saving-investment imbalances and increasing external vulnerabilities. Wealth gains have accrued in large part to high-income households, with affordability deteriorating significantly for the rest of the population. Although house prices have fallen since the global financial crisis, they remain at relatively high levels. These economic and social challenges remain daunting.

Imbalances in housing markets can distort incentives and lead to a misallocation of resources, with adverse efficiency effects and distributional consequences. While housing booms were widespread in the OECD area, domestic structural inefficiencies appear to have magnified the effect on New Zealand's property prices. These reflect a combination of tax incentives, regulatory constraints on supply and a lack of alternative viable investments for long-term wealth creation. This paper examines the role of these various structural factors in inflating property prices and potential policy options to rebalance housing markets in the pursuit of more sustainable growth. Residential mobility has traditionally been relatively high in New Zealand (OECD, 2000b) and appears to be facilitated by relatively low transactions costs and weak rent controls, so these issues are not discussed in this paper.

\section{Features of the housing boom}

Housing plays an important role in New Zealand's economy, with residential investment accounting for almost 7\% of GDP at the peak of the boom, and real estate services constituting about $13 \%$ of the economy's total value added. Between 1990 and 2001, national average house prices had appreciated at an annual rate of only $2 \%$ in real terms and even fell in a number of districts. However, from around 2002 house prices increased in concert across all regions and local districts, and since then, cumulative growth in the national house price index has exceeded that of most other OECD countries (Figure 1). At their high point in 2007, NZ house prices had risen over $180 \%$ in real terms relative to 1990 levels, and all local districts experienced at least an $85 \%$ increase. ${ }^{2}$ The strongest gains exceeded $200 \%$ in real terms and were

1. Economist in the OECD Economics Department. This paper reports on background work for the 2011 OECD Economic Survey of New Zealand, published under the responsibility of the Secretary General. The author is grateful for the valuable discussions and comments received from colleagues including Thomas Alastair, Christophe André, Dan Andrews, Alexandra Bibbee, Aida Caldera Sánchez, Andrew Dean, Robert Ford, Peter Jarrett, Tadashi Matsumoto, and Deborah Roseveare, as well as officials from the New Zealand government. Special thanks go to Françoise Correia for statistical assistance and to Mee-Lan Frank and Maartje Michelson for editorial support.

2. House price growth is based on the QVNZ index, which is constructed by taking the sales price relative to the current government rating valuation of a property, which provides an inherent quality adjustment, 
concentrated in major urban centres and vacation spots located in accessible sunny or coastal regions. Roughly $86 \%$ of the population lives in an urban centre, and over one-third of New Zealanders live in Auckland.

This surge in real house prices appears to have been triggered by the combination of a sharp net inflow of migrants and easy credit conditions. External migratory flows can be large and volatile in New Zealand, placing significant pressures on housing demand. Net inflows in 2002 and 2003 combined to almost $2 \%$ of the entire population and have remained positive every year since (Figure 2, Panel A). With similar developments occurring in Australia, abundant immigration has fuelled faster population growth in the Australasian region than in most other advanced economies since 2001 (Tumbarello and Wang, 2010). Given the close ties between the two countries, a common Australasia-wide macroeconomic trend appears to explain over $90 \%$ of movements in NZ house prices, giving rise to what amounts to a single housing market across both countries (Grimes et al., 2010). The surge in net migration occurred at a time when mortgage rates were at low levels compared to the late 1990s (Figure 2, Panel B). Together with low inflation, these developments significantly increased the amount that households could borrow without raising debt-servicing burdens, thus allowing them greater buying capacity in the housing market. Strong gains in the terms of trade during this period probably also played a role, as dairy price rises drove up rural land values, with spillovers into regional house prices.

Lags in the response of residential construction to the positive demand shock prolonged the upward pressure on prices, with reports in early 2007 that the contracting industry was working at full capacity and that significant shortages existed in materials as well as skills in the engineering profession (Local Government Rates Inquiry Panel, 2007). The cost of building a home also ratcheted up by over $60 \%$ between 2002 and 2007 (Page, 2009). This largely reflected the surge in commodity prices and labour shortages, but also a decline in construction industry productivity, discussed in Box 3 below.

\section{Figure 1. Housing price indexes across countries}

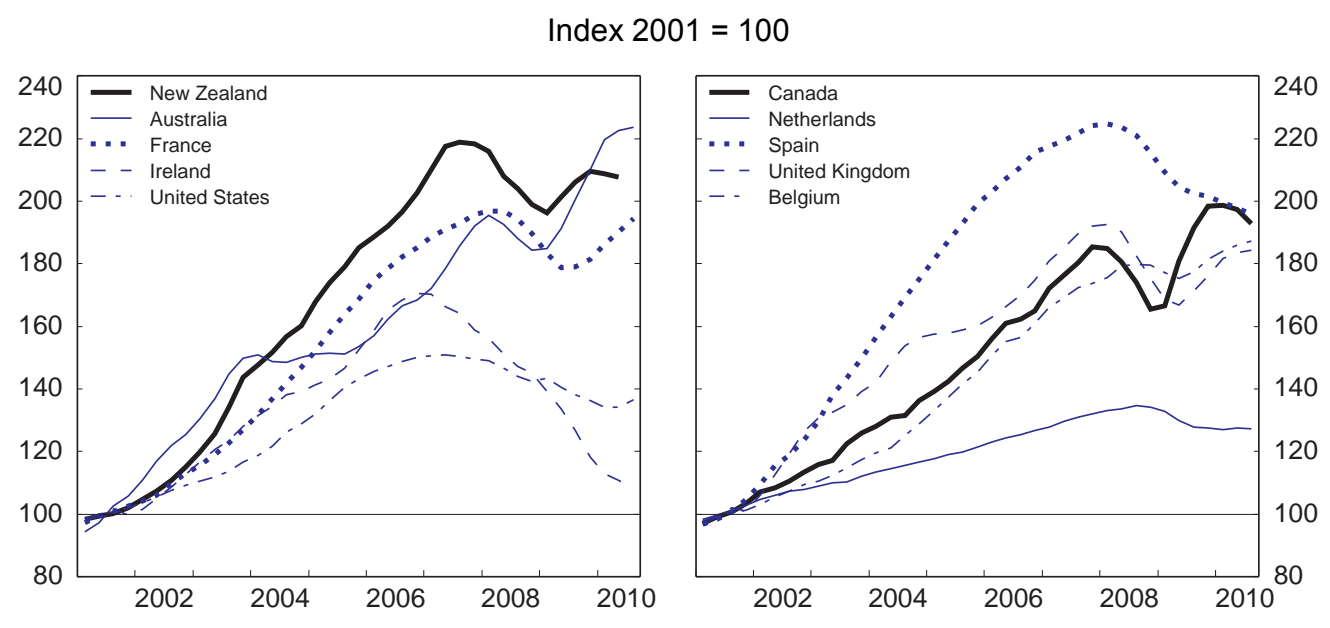

These factors likely inflated expectations of future house price appreciation. Though it is difficult to determine whether a bubble had formed, various affordability and relative price measures had reached levels that were well above long-term norms. In particular, house prices increased sharply relative to disposable income during this period. Rent increases remained relatively muted, growing roughly at the pace of overall CPI inflation. As a result, the price-to-rent ratio increased steeply from 2001 to 2007, after

assuming the underlying rating valuation is correct. The rating value is based on assessments conducted by local councils every three years. 
having remained flat since 1970 (Figure 3). This ratio can be interpreted as the cost of owning relative to renting a house. With the substantial increase since 2001, demand would be expected to eventually shift in favour of renting, reducing pressure on house prices. However, there may be several reasons why renting and owning are far from perfect substitutes, particularly if distortions exist in rental markets (Girouard et al., 2006). In general, none of these ratios provide an accurate assessment of sustainability or affordability, since they are based on average measures, whereas housing markets tend to concern higher-income segments of the population. Furthermore, they do not account for changes in the user cost of housing. Although a number of econometric studies suggest that NZ housing prices were overvalued by up to $25 \%$ during the boom period (Fraser et al. (2008); van den Noord (2006)), prices have fallen only slightly since the economic downturn. These prices reflect a thin market, however, as sales volumes have fallen steeply and remain $50 \%$ below peak levels.

Figure 2. Macroeconomic indicators

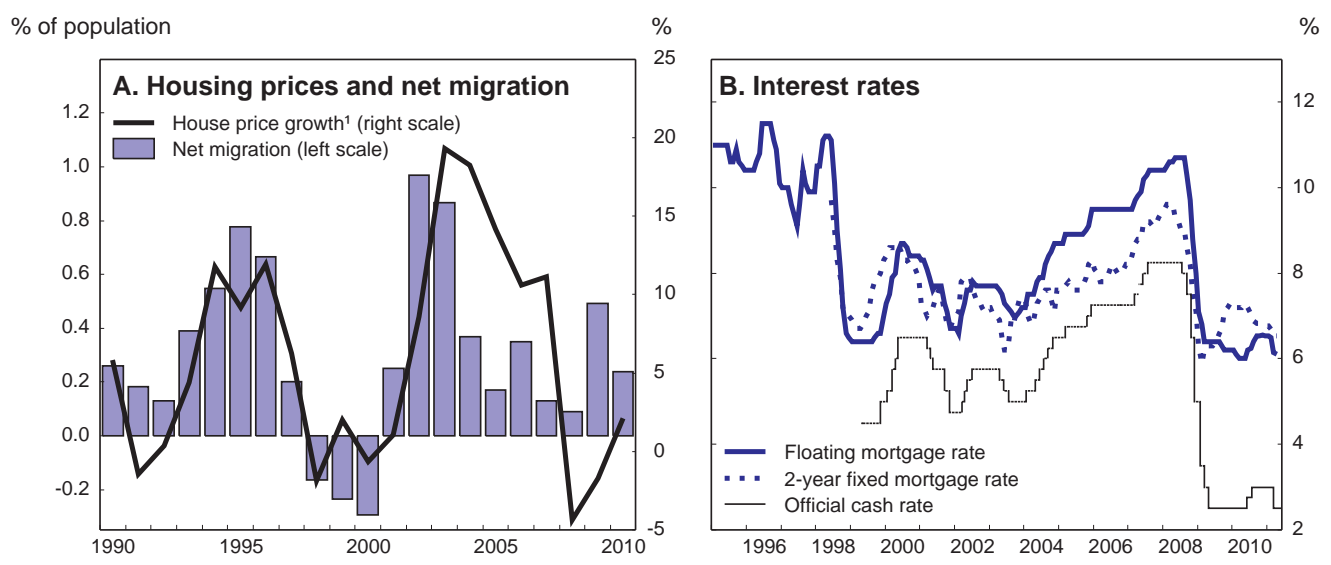

1. House price is the Quotable value Ltd house price index, house only; percentage change from previous year.

Source: ANZ; Reserve Bank of New Zealand; Statistics New Zealand; and OECD Economic Outlook 89 database.

Figure 3. Housing price ratios

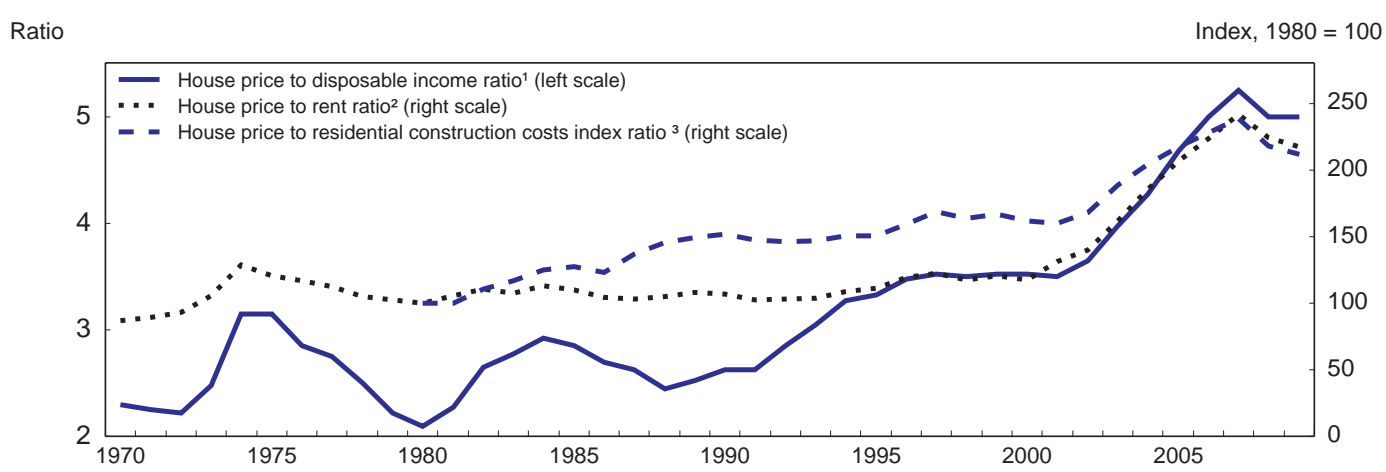

1. House price is the Quotable Value Ltd house price index.

2. Rent is the CPI Actual rentals for Housing.

3. The residential construction costs are estimated by the capital goods price index for dwellings and outbuildings.

Source: Statistics New Zealand; Reserve Bank of New Zealand; Girouard et al. (2006); OECD Main Economic Indicators database; OECD calculations. 
Evidence that affordability has worsened for the average household may be better revealed by a growing "intermediate" market segment. This is identified by the number of households in the private rental market with at least one household member in paid employment, but who cannot afford to buy a house at the lower-quartile house price under standard bank lending terms. The latter is assumed to comprise a $10 \%$ deposit and no more than $30 \%$ of the household's gross income spent on mortgage payments at the one-year fixed mortgage rate. Census data indicate that the proportion of households renting in the private market who could not afford to buy a house more than doubled to $58 \%$ between 2001 and 2006 (DTZ, 2008).

The financial sector is heavily exposed to property markets, with residential mortgages accounting for over $50 \%$ of total bank and non-bank financial institution loans (Figure 4 ). However, it is likely that a sizeable portion (perhaps up to $20 \%$ ) of residential mortgage loans reflect borrowing by households to finance their small businesses; unfortunately, data limitations prevent any accurate identification of these loans. The cooling in housing markets since 2007 has had only moderate repercussions for the wider financial system thus far, given the limited extent of mortgage securitisation or exposure to sub-prime mortgages, as well as banks' relatively conservative lending practices. Most banks require at least a $20 \%$ deposit to purchase a home and mortgage payments to not exceed $30 \%$ of household gross income. For loans greater than $80 \%$ of property value, premiums are charged for mortgage indemnity insurance, which insures the lender against any loss. The bankruptcy laws further discourage default by making borrowers liable for any remaining debt after their homes have been repossessed. Although the share of new mortgages with loan-to-value (LTV) ratios higher than $80 \%$ rose to above one quarter by early 2007 , it is likely that these contracts largely reflected investment properties acquired by high-income homeowners who often use their primary residences as collateral. ${ }^{3}$ Nonetheless, the subsequent economic downturn led to the failure of numerous non-bank finance companies, which had been an important source of financing for property development.

Figure 4. Lending by financial institutions to housing, business and agriculture

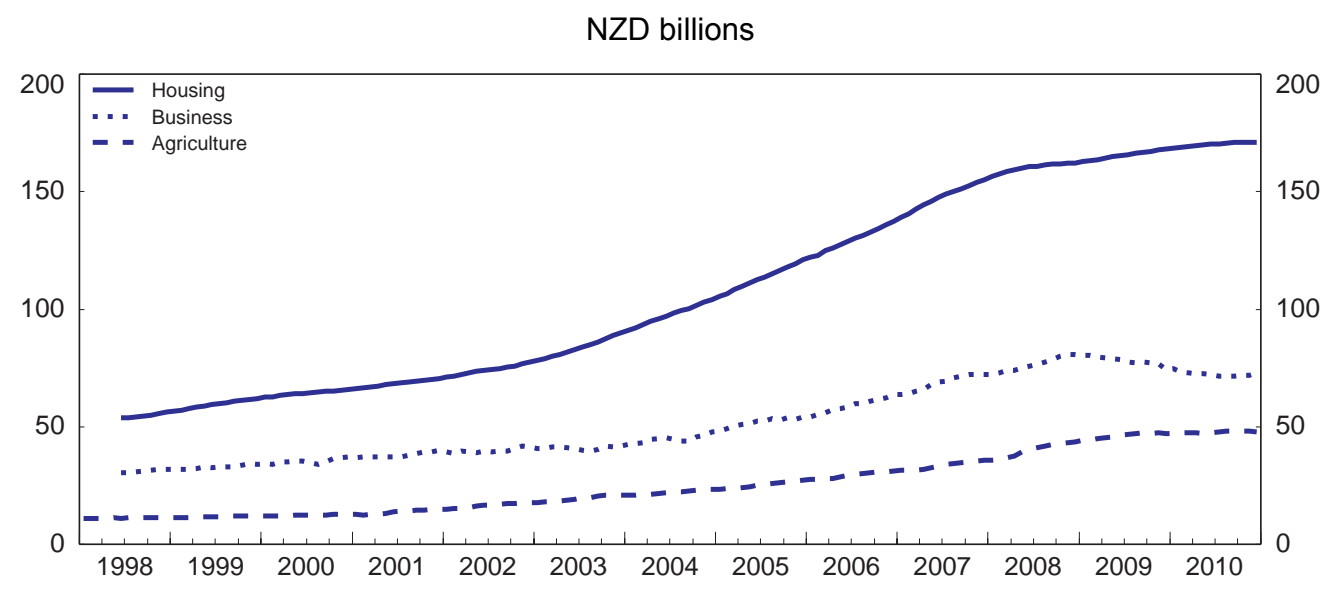

Source: Reserve Bank of New Zealand.

Household debt levels have accelerated since the early 2000 s and remain close to $170 \%$ of disposable income, high by OECD standards (Figure 5). As interest rates began to pick up at the end of 2003, debt-service ratios also rose and crested at $15 \%$ of disposable income by the end of $2008 .{ }^{4}$ However,

3. This information is based on various discussions with government and private-sector analysts, as well as studies conducted by the RBNZ (for example, Briggs, 2007).

4. The majority of mortgage contracts are on fixed rates of less than one year. 
analysis of data from the 2007 Household Economic Survey indicates that only 50\% of homeowners have a mortgage, representing only $35 \%$ of all households (Kida, 2009). Most mortgage debt tends to be held by higher-income households, with those in the top two income quintiles accounting for almost three quarters (Kida, 2009). This analysis also shows that only $0.1 \%$ of indebted households in 2007 would be considered highly vulnerable, as defined by having LTV ratios above $80 \%$ or debt-service ratios above $55 \%$. Declining house prices would most affect those with elevated LTV ratios, who tend to be high-income households (Figure 6, Panel A). Meanwhile, a shock to interest rates or income would create the most difficulties for those with hefty debt-service burdens, which are largely concentrated among low-income households (Figure 6, Panel B). As the share of loans on floating rates has increased since the economic downturn, reaching $50 \%$ towards the end of 2010 , households may be more exposed to an eventual rise in interest rates. On the whole, mortgage delinquency rates have remained comfortably low at $1.3 \%$ in the first half of 2010, as compared to about $10 \%$ in the United States.

\section{Figure 5. Household debt ${ }^{1}$}

As a percentage of gross disposable income

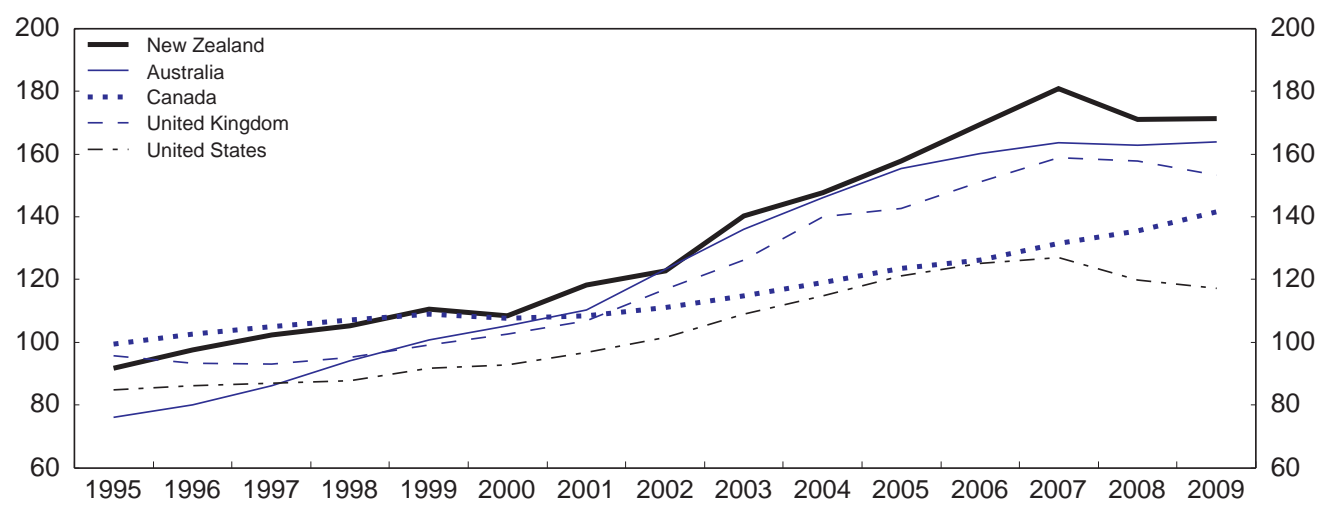

1. Short- and long-term loans.

Source: Statistics New Zealand and OECD National accounts database.

Figure 6. Household indebtedness across income quintiles
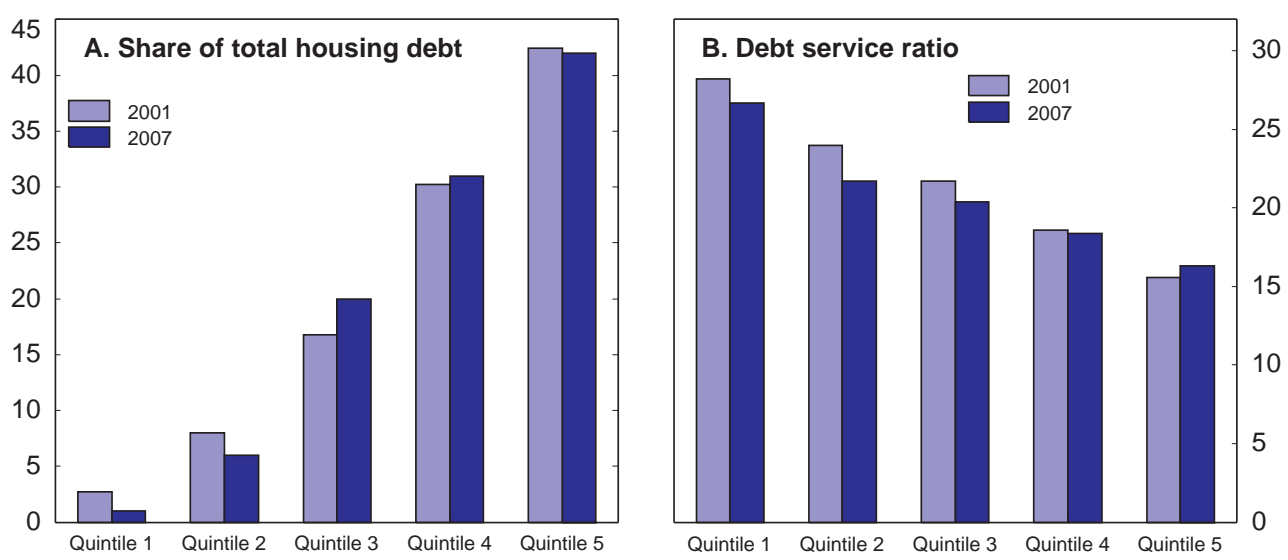

Source: Reserve Bank of New Zealand. 


\section{The nature of housing demand}

\section{Owner occupants}

Despite the increase in housing demand since 2002, owner-occupancy rates declined over this period. The share of owner-occupied housing in New Zealand is slightly below the OECD average (Figure 7) and has been on the decline since peaking at $76.7 \%$ in 1986. This contrasts with the trend of increasing owner-occupancy rates observed in most other OECD countries. As of the 2006 census, $67 \%$ of New Zealand households were owner-occupiers, while $27.5 \%$ rented on the private market and $5.5 \%$ lived in social housing. Declining owner-occupancy rates reflect in part the trend towards postponing household formation until later in life, which has accompanied the increasing uptake of tertiary education and changing social dynamics. Reduced affordability has also played a role, as additional analysis suggests that between 1991 and 2006, the likelihood of owning diminished considerably faster for those on relatively low incomes than it did for the population as a whole (Morrison, 2008). These factors have lowered home-ownership rates among young households in many countries (Scanlon and Whitehead, 2004), but in some cases have been offset by the movement of large cohorts into older age groups with higher rates of ownership (Yates, 2000). In New Zealand, however, home ownership rates have fallen in all but the oldest age groups and across all income deciles (Morrison, 2008), suggesting the possibility of a structural shift in the housing market for which the exact reasons remain unclear.

\section{Figure 7. Tenure structure across countries}

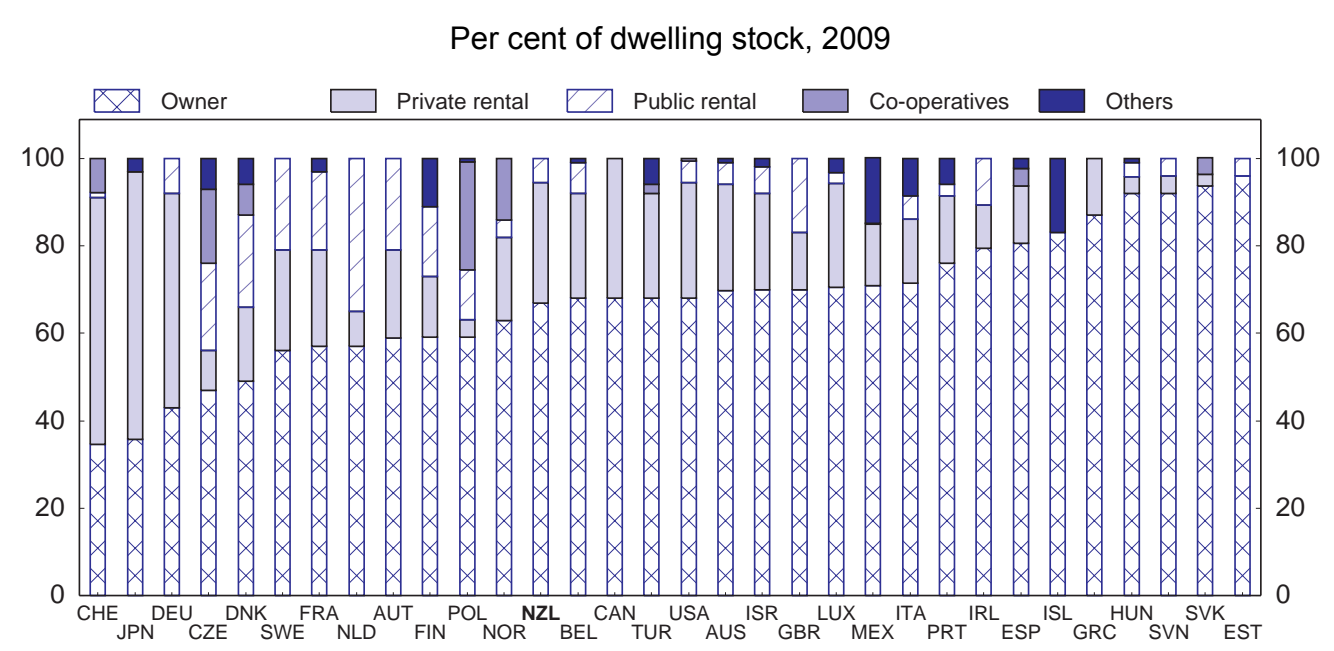

Source: Andrews, D. A. Sanchez and A.. Johansson (2011), "Housing Markets and Structural Policies in OECD Countries", OECD Economics Department Working Papers, No. 836, OECD Publishing, Paris.

Specific events like partnering, break-ups, parenthood and employment changes tend to prompt tenure transition, with marriage and childbearing remaining the dominant drivers of the propensity to own (Morrison, 2008). In this regard, a decline in the proportion of couples with children from $34 \%$ of all households in the 1991 census to $27 \%$ in 2006 may explain some of the downward trend in home ownership. However, even for couples with children the probability of ownership declined by over 10 percentage points at the younger age groups between 1991 and 2006 (Morrison, 2008). Understanding the drivers of these trends is complicated by the endogeneity of household formation to the relative cost of housing. While house prices fluctuate with changes in demand, household formation decisions may in turn depend on the relative costs of renting or staying in the family home. For example, couples may decide to defer having children until they become owners, since accumulating sufficient funds for the deposit often requires both parents to work full time. 
Although strong population growth and easy credit prompted the housing boom to get underway in 2002, the prolonged price increases that ensued do not appear to have been driven entirely by greater demand for housing services relative to other goods and services. For one, owner-occupancy rates continued to decline throughout the period (affordability issues aside) and rent prices increased in line with the CPI. Although the average size of new houses increased by about 10 square metres from 2002 to 2007 (Figure 8), the quality adjustment in house prices would normally remove this effect. With the strongest price increases observed in big cities and "sunshine" regions, these developments signal an increasing demand for holiday homes and rental properties in areas with capital gains potential. Additionally, housing construction failed to keep pace with the growth in household formation over this period, indicating an important role for tightening supply conditions (Figure 8). However, the total stock of private dwellings exceeded the number of households by about 5.2\% in 2010, up one percentage point from the early-1990s, suggesting no overall lack of supply at the aggregate level (although it does not rule out regional shortages or unfulfilled size or tenure preferences).

\section{Figure 8. Number and size of private dwellings}

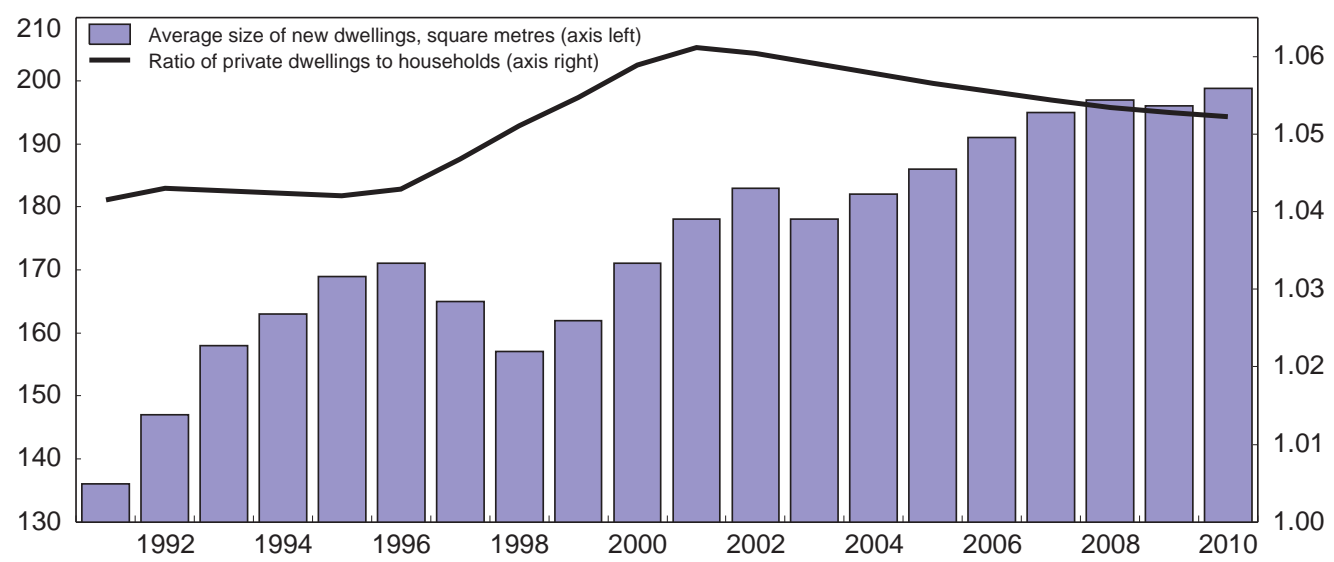

Source: Statistics New Zealand.

\section{Rental property investors}

Although limited data make it difficult to distinguish the role of property investment in driving housing demand, various information sources suggest it was an important factor. Census data indicate that the share of housing stock owned by private-sector landlords increased from $15 \%$ in 1996 to $20 \%$ in 2006 . Data from the Household Economic Survey and other sources suggest that by 2007 investment properties accounted for up to $40 \%$ of all residential mortgages (Brooks and Cubero, 2009). Estimates from the Survey of Families, Income and Expenditure (SoFIE) conducted in 2003-04 suggest that about $15 \%$ of households owned an investment property (Scobie et al., 2007), of which roughly half were rental properties and the remainder holiday homes, timeshares and overseas property. About two-thirds of rental properties are standalone houses, rather than multi-unit dwellings.

The rental property market is characterised by numerous small proprietors rather than institutional investors (DTZ, 2004). Information from the annual ANZ Property Investment Survey, completed by about 1000 investors nationwide, indicates that the majority (about 60\%) are small-scale "mom and pop" entities, with less than $10 \%$ engaging as full-time property investors. Over $80 \%$ of those who invest in residential properties own more than one property, with the median at three, and intend to hold them for the longer term. Three-quarters of property investors are in the top half of the income distribution, with an average before-tax income of NZD 80 000-90 000 per year. 
The majority of investors buy rental properties close to where they live, and so the regional pattern of demand appears to follow the population distribution fairly closely, with the bulk in the major urban centres of Auckland, Wellington and Christchurch. However, popular vacation destinations tend to be regions for which the share of rental property demand exceeds their population share. Based on the 2003 National Landlord Survey from the Centre for Research, Evaluation and Social Assessment, the most popular reasons cited for owning rental property are prospective capital gains (38\%), regular income stream $(32 \%)$ and retirement income $(25 \%)$.

\section{Are households' portfolios too concentrated in housing?}

Although it is unclear to what extent NZ households under-save relative to others, a disproportionately large amount of household savings appears to be held in the form of housing, land or other durables compared to other OECD countries (Figure 9). As of 2008, non-financial assets accounted for over $75 \%$ of total NZ household assets, versus an unweighted average of $50 \%$ for 14 other OECD countries for which comparable data are available. The swelling in NZ property and land values relative to income levels since the early 2000 s appears to account for about 10 percentage points of this gap. However, these data exclude household investments in overseas assets, unincorporated businesses and unlisted incorporated businesses, which may be more important in New Zealand than elsewhere, given its relatively under-developed domestic financial markets and large farming sector. Furthermore, the aggregate data conceal a highly skewed distribution, with Le et al. (2010) finding that financial and other non-housing assets are relatively important components of net worth only for individuals in the top two deciles of the wealth distribution. New Zealand's higher concentration of wealth held in the form of housing may reflect in part tax incentives to own housing or supply restrictions that have inflated the price of property, discussed in the next two sections. However, it is likely that other factors play a role, given that many countries also provide generous tax treatment for housing, and face similar or even more onerous supply constraints (Sánchez and Johansson, 2011). The rest of this section discusses other possible reasons why NZ households may favour housing in their portfolio allocation, and the potential benefits and risks associated with that choice.

Figure 9. Financial and non-financial assets as a percentage of net disposable income

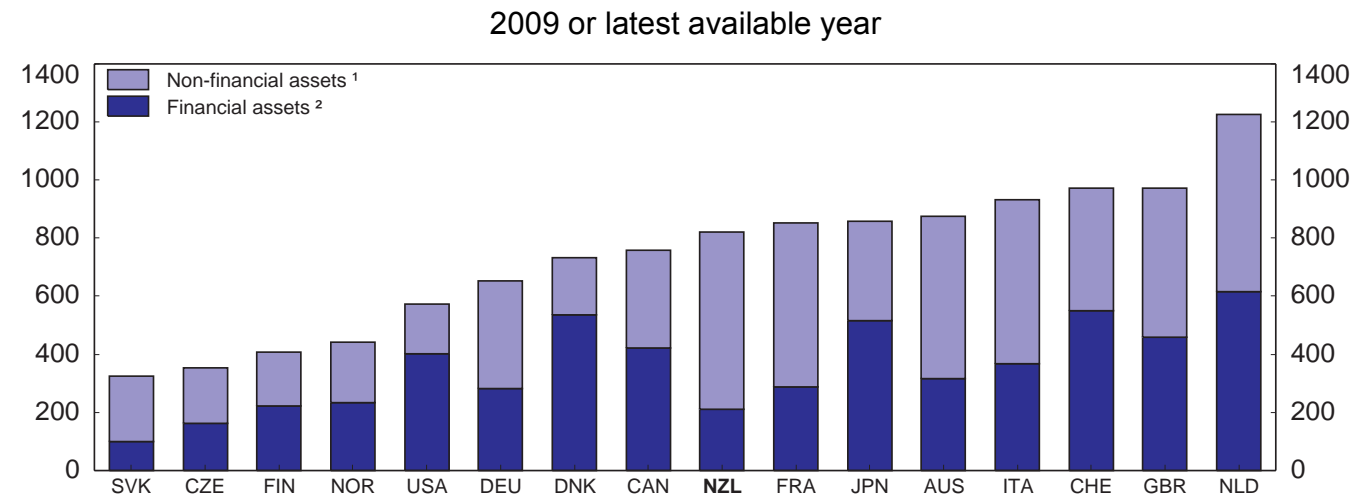

1. Include dwellings, land and consumer durables. Dwellings only for Denmark, Finland, Norway and Slovakia.

2. Balance sheet consolidated for Australia, balance sheet non-consolidated for the other countries and Reserve Bank of New Zealand data for New Zealand.

Source: Reserve Bank of New Zealand; OECD National Accounts database and OECD Economic Outlook 88 database.

Purchasing a house is both a consumption decision and an investment decision. As an investment, housing differs fundamentally from other household assets in that it provides not only an important flow of services, but also a significant value in excess of that service flow during the lifetime of the owners 
(Sun et al., 2007). Also, without home ownership, rent would absorb a significant proportion of household expenditure, so this additional value provided by home ownership insures the owner against fluctuations in the cost of such housing services (Sun et al., 2007). ${ }^{5}$ Over the long term, home ownership can ensure a sufficient level of residential comfort in retirement when income is typically low (van Suntum, 2009). Purchasing property may also facilitate long-term consumption smoothing over the life cycle via compulsion: through the obligation of mortgage payments, many households increase their home equity and save more than they otherwise would. ${ }^{6}$

As discussed earlier, the growth in NZ real estate demand in recent years appears to reflect the increasing role of housing for investment purposes. This desire to accumulate housing assets may reflect widespread expectations that home ownership produces superior and more stable returns relative to alternative investments for long-term wealth creation. Many households view ownership as an eventual source of retirement income that can be tapped via capital gains from the sale of investment properties, down-sizing or reverse mortgages. The reverse mortgage market has grown significantly in countries like the United States, the United Kingdom, Canada, Australia, the Netherlands, Spain and Sweden, although overall equity release still constitutes a very small proportion of total housing-related financial products (DEMHOW, 2010). In New Zealand, the use of reverse mortgages among older households is a fairly recent phenomenon, with outstanding loans worth NZD 447 million (roughly 6500 contracts) as of December 2009, or roughly $0.2 \%$ of total household financial liabilities (Deloitte, 2010).

The evidence that home ownership is a superior vehicle for long-term wealth creation is mixed. Sun et al. (2007) find that a retirement strategy that includes the funds from a reverse mortgage among the assets to decumulate can generate superior average returns to one that depends predominantly on drawing down financial wealth. The strategy can be risky, however, particularly if the household lives longer than expected or unanticipated events require the house to be sold after equity has been significantly reduced. An examination of prices of housing relative to equities across countries over the past three decades shows no tendency for property to systematically outperform stocks over the long term (Figure 10). In New Zealand's case, however, homeowners on average would appear to have enjoyed superior returns to their shareholding counterparts over the late 1980s and for virtually the whole of the 2000s. Nonetheless, studies show that housing prices have a large idiosyncratic component, and the returns to investing in a particular house are considerably riskier than suggested by analysis of national or regional house price indexes (Case and Shiller, 1989). While shares may also be risky, they can be transacted in smaller sums and complemented with a wide range of instruments, thus allowing greater possibilities for asset diversification.

The extent to which NZ households' investment portfolios are concentrated in housing assets is disquieting, given the lack of certainty over the returns to housing over the long term. For example, demographic factors may affect returns if selling pressure from a rising share of retirees squeezes capital gains (Bollard et al., 2006). Improving portfolio diversification will remain a challenge in New Zealand, however, as long as shallow capital markets limit the availability of viable alternative investments. Domestic capital markets are relatively shallow by advanced economy standards. Having peaked at over $50 \%$ of GDP in 1997, stock market capitalisation shrank progressively to reach $25 \%$ of GDP in 2009 , whereas in Australia it swelled from $70 \%$ of GDP to $180 \%$ over the same period. In turn, financial deepening is restrained by the low level of household savings outside of housing and the relatively large

5. This excludes changes in property tax, utility expenses and maintenance expenditures.

6. Behavioural economic theories suggest that people tend to save more if it is done automatically, rather than having to choose to set aside an amount each month. 
Figure 10. House prices relative to share prices

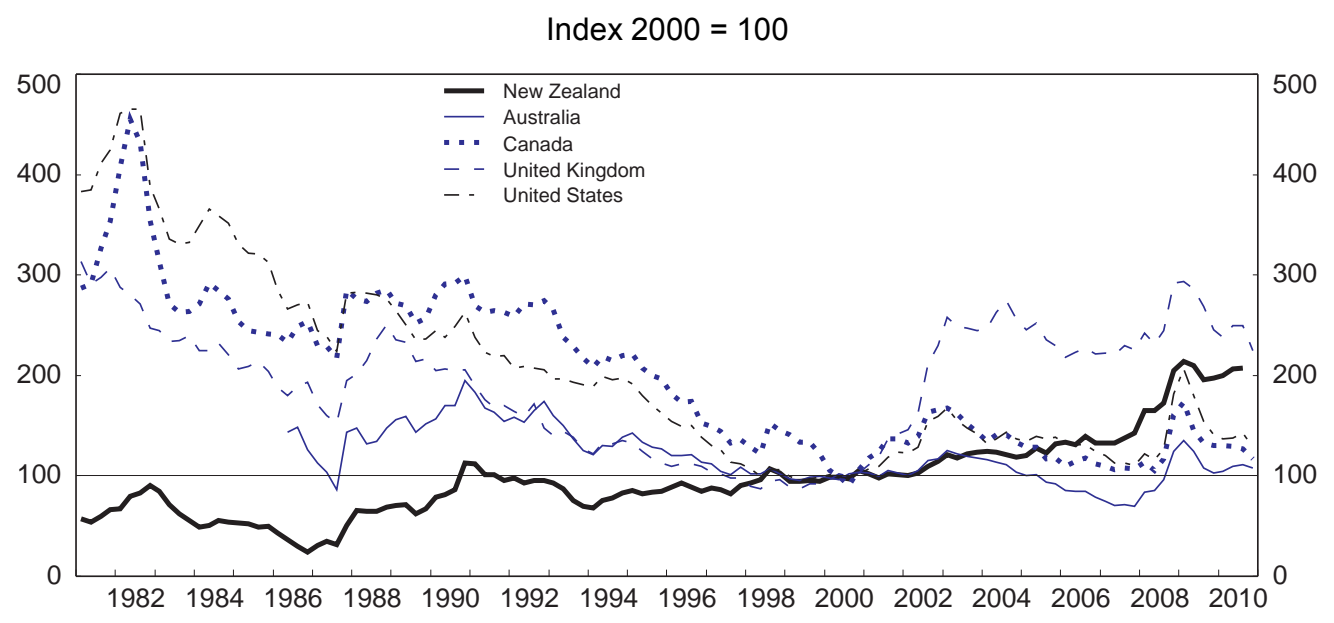

Source: Thomson Datastream and OECD, Main Economic Indicators database.

share of banking-sector assets tied up in residential mortgage loans (Figure 4). Household confidence in financial markets has been low since the crisis that followed financial market reforms in the late 1980s, followed later by the recurrent failure of major finance companies in 2006 and again more recently. Furthermore for owner occupiers, favourable tax treatment (discussed in more detail below) makes paying off the mortgage the optimal saving strategy, rather than diversifying the portfolio of assets (OECD, 2000a). However, the development of KiwiSaver, a tax-favoured retirement savings scheme introduced in 2007, could help divert savings towards alternative investments and eventually contribute to deepening financial markets over time.

\section{The role of favourable tax policies}

Reviews of tax systems across countries find that most OECD countries treat owner-occupied housing favourably relative to other forms of investment (Andrews et al., 2011; Scanlon and Whitehead, 2004) and often encourage households to use their homes for long-term private wealth accumulation and even retirement income (van den Noord and Heady, 2001). These advantages are generally provided through non-taxation of imputed rental income and capital gains, low property taxes and mortgage-interest deductibility. Most OECD countries effectively exempt primary residences from capital gains taxation, but most do at least apply an inheritance tax, and almost three quarters tax capital gains on secondary residences (Annex).Meanwhile, most OECD countries treat rental properties as an investment good, taxing capital gains and rental income, while allowing deductions for mortgage interest and other expenses. To achieve complete neutrality, owner-occupied housing would be treated as any other investment for tax purposes in the sense that rental income would be imputed for tax purposes and capital gains would be taxable, with mortgage interest payments fully tax-deductible.

Policies that favour housing may be motivated by the view that home ownership is a social good that assists family stability and the continuity of educational opportunities for children. Studies show that owner-occupancy tends to generate positive externalities such as safer and more stable neighbourhoods and improved educational outcomes for children (DiPasquale and Glaeser, 1999; Green and White, 1997; Coulson, 2002). These findings, however, tend to suffer from identification problems associated with endogeneity. In practice, there are strong indications that such tax policies tend to become capitalised into higher house prices and lead those who can afford it to buy more or larger homes than otherwise (van den Noord and Heady, 2001; Hargreaves, 2008; Andrews et al., 2011). Greater wealth inequality and 
reduced labour mobility associated with rising home ownership may be other potential consequences. Policymakers should thus more carefully weigh these possible adverse effects against any social benefits of such policies. Another rationale for policies that subsidise housing may be to promote private retirement savings as ageing populations increase pressures on public pension systems. However, adopting such policies as a substitute to pursuing public pension sustainability magnifies the long-term risks for those unable to afford ownership, thereby exacerbating inequalities (Doling and Ronald, 2010).

\section{Tax distortions have been significant}

The tax system in New Zealand (see Table 1 for details) exempts imputed rent and capital gains from taxation, which creates advantages for owner-occupied housing in a similar way to other OECD countries, except that mortgage interest is not deductible. For residential property investors, the tax treatment of income and expenses is similar to other investments in the sense that rental income is taxed as ordinary income at the marginal tax rate, while all related expenses incurred including mortgage interest can be deducted. However, property investors in New Zealand enjoy generous tax treatment because of the lack of capital gains tax and the extent to which losses can be offset against other income.

Table 1. Taxation of housing in New Zealand

\begin{tabular}{lll}
\hline Form of taxation & Owner-occupier & Rental property investor \\
\hline & & \\
Tax on rental income or imputed rent & No & Taxed at marginal tax rate \\
Capital gains tax & No & No \\
Mortgage interest tax deductibility & No & Deductible at marginal tax rate \\
Property/Land tax & Nes & Yes, deductible at marginal tax rate \\
Inheritance/Estate Tax & No & No \\
Transfer taxes or stamp duties & No GST on & No GST on rent. GST is imposed on the \\
GST & imputed rent. & cost of building new houses. \\
& GST is imposed & \\
& on the cost of & \\
& building new & \\
& houses. & \\
&
\end{tabular}

Source: Inland Revenue Department.

New Zealand is one of the few OECD countries with no comprehensive capital gains tax on any asset class (Annex ). ${ }^{7}$ Because the nominal returns on interest-bearing assets are taxed, when the inflation rate is positive the absence of a capital gains tax creates incentives to invest in assets that earn nominal capital gains (i.e. property and shares), rather than interest. Although share investments for the most part also earn tax-free capital gains, dividend payments are often subject to taxation under a full imputation system that results in a net top tax rate of $11.4 \%$ (Chen and Mintz, 2009). This tax treatment encourages both rental property investment and purchase of owner-occupied housing. Property investments also become more attractive because the collateral value enables the individual to incur significantly higher leverage compared to other assets, which magnifies the potential for returns. The tax advantages to investing in housing relative to other financial assets increase with income levels and are illustrated in Figure 11. This stylised scenario indicates that for a given rate of return, an investor in the top marginal tax bracket could face discounts in the real effective tax rate (as a percentage of real income) of as much as $50 \%$ on owner-occupied housing and $25 \%$ on rental property, compared to debt instruments.

7. However, some specific capital gains are taxed to varying degrees, such as on land and property sales if they were purchased for profit-making purposes such as in the case of developers or traders, as well as on foreign shares and some intellectual property. 
Figure 11. Real effective tax rates on different investment vehicles ${ }^{1}$

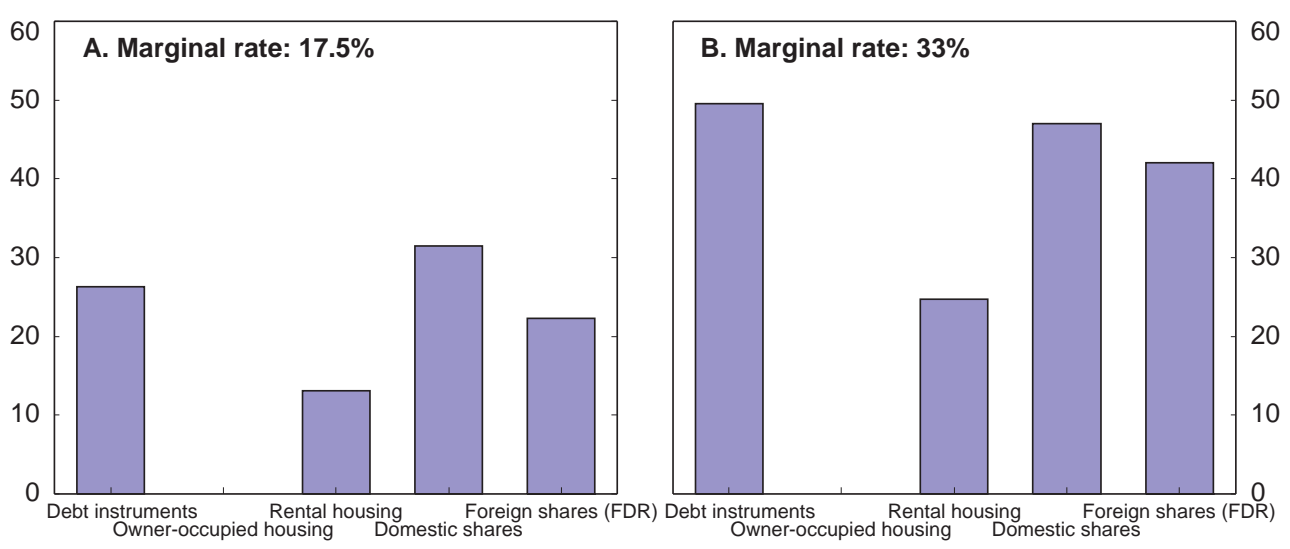

1. These calculations assume a $6 \%$ rate of return on all assets. For shares, it is assumed that $66.6 \%$ of the return was paid in dividends, $33.3 \%$ was retained. For rental housing $50 \%$ of the return is assumed to be in the form of rental income and $50 \%$ in the form of capital gains.

Source: The Treasury (2010), Savings in New Zealand, Issues and Options, September.

Rental property investors have benefited from several other tax provisions. One is that any losses on their investments can be deducted against labour income at the marginal income tax rate in order to reduce tax liabilities, while still being able to reap tax-free capital gains. This "negative gearing" has been widely advertised as a benefit to investing in housing and has led to an expansion in the use of Loss Attributing Qualifying Companies (LAQCs) for property investments. Until the 2010-11 budget changes (described below), these were companies with special tax status enabling their shareholders to claim losses against their personal income at their marginal tax rate. For high-income investors facing the top marginal tax rate, setting up LAQCs for their rental properties enabled arbitrage opportunities since the company profits could be taxed at the lower corporate tax rate. These opportunities increased when the top marginal tax rate was raised from $33 \%$ to $39 \%$ in 2000 , while the corporate tax rate remained at $33 \%$. Indeed, net rental income has declined markedly since 2000, with increasing losses claimed by LAQCs. Between 2003 and 2007 the number of active LAQCs doubled, and the average tax loss claimed by investors increased by almost 50\% (TWG, 2010). Survey data further suggest that since 2006 roughly half of all property investors have reported losses on their investment properties, and a similar share have structured them as LAQCs (ANZ, 2007, 2008 and 2009).

On net, losses on rental property investments amounted to about NZD 0.5 billion in 2008, implying about NZD 150 million in tax revenue losses (or $0.2 \%$ of total revenues). Furthermore, the deduction of losses on rental properties from personal income allowed an estimated 9700 additional families to gain eligibility for receiving tax credits from Working for Families, a programme providing assistance to low-income families (TWG, 2010). Until the most recent budget reforms, depreciation on rental properties was also tax-deductible until $13.5 \%$ of the original value was reached. Without a capital gains tax, this provision created asymmetries by allowing accruals-based depreciation on investment property without any equivalent tax on appreciation, although investors were required to pay back any tax benefit from depreciation deductions upon sale in the event that the property value had actually appreciated on net. These allowances were found to be relatively generous by international norms (Chen and Mintz, 2009) and may have offered a tax shelter for income from other sources. ${ }^{8}$

8. For buildings with a 50-year economic life, this system implied a depreciation rate of $4 \%$ per year. This rate is equivalent to a double-declining balance approach that may have been too high for rental property, given that a straight-line system would imply a 2-3\% depreciation rate. Furthermore, investors often 
The result of these different tax provisions is that buying a home with mortgage debt is more advantageous for the rental property investor than the owner-occupier, because of the wide ranging opportunities to deduct losses. Moreover, high-income investors accrue larger benefits than low-income investors, since expenses and losses are deducted at the marginal tax rate. These tax incentives generate added demand for rental property investments, which may influence tenure decisions and have important implications for owner-occupancy rates, for example, by making it advantageous for individuals to purchase a rental property to lease out, while continuing to live in rented accommodation themselves. Once the mortgage is paid off, however, the tax advantage then shifts in favour of owner-occupiers who enjoy tax-free imputed rental income. The potential effect of these various tax advantages on housing values is illustrated in Box 1.

\section{Box 1. The effect of New Zealand's tax system on housing values}

The impact of housing taxation on property values can be approximated using a discounted cash-flow model based on the user cost of housing, as applied by Hargreaves (2008), Girouard et al. (2006) and Poterba (1992). In this model, the equilibrium value of a house is that which equates the after-tax returns to the corresponding cost of holding the property. As a baseline scenario with no distortions, housing is taxed in the same way as other investments, with taxation of rental income and capital gains at the same rate, and tax deductibility for mortgage interest and other user costs of housing. Assuming the property is purchased with a mortgage loan worth $80 \%$ of the value $(\mathrm{V})$, the equilibrium condition can be represented as:

$A\left(1-t^{j}\right)+V g\left(1-t^{c}\right)=(0.8 V i+V f)\left(1-t^{j}\right)+0.2 V r\left(1-t^{c}\right)$

where $A$ is the annual rent, $t^{j}$ is the marginal income tax rate, $g$ is the expected capital gain, $t^{c}$ is the capital income tax rate, $l$ is mortgage interest rate, $f$ is the user cost of ownership as a percentage of the property value (including local property tax), and $r$ is the rate of return on a bank deposit or alternative investment. The final term on the right-hand side of the equation thus represents the opportunity cost of depositing the $20 \%$ down-payment in a bank account.

The impact of New Zealand's housing taxation on this value can be illustrated with a numerical example. Assuming the property buyer faces annual rental income $(A)$ of NZD 5840 , a top marginal income tax rate $\left(t^{j}\right)$ and capital income tax rate $\left(t^{C}\right)$ both equal to $33 \%$, a mortgage rate $(i)$ of $8 \%$, ownership costs $(f)$ of $2 \%$ of the property value, a bank deposit rate $(r)$ of $7.2 \%$, and expected capital gains of $4 \%$, the undistorted equilibrium purchase price of the property under a perfectly neutral tax system is then:

Undistorted value:

$$
V=\frac{A\left(1-t^{j}\right)}{\left(0.8 i+f\left(1-t^{j}\right)+(0.2 r-g)\left(1-t^{c}\right)\right.}=\mathrm{NZD} 100000
$$

In New Zealand, rental property investors are not taxed on capital gains. For investors purchasing with an $80 \%$ mortgage, this distortion inflates the property valuation by over $50 \%$ relative to the undistorted value:

Mortgaged rental property investor value: $V=\frac{A\left(1-t^{j}\right)}{\left(0.8 i+f\left(1-t^{j}\right)+0.2 r\left(1-t^{c}\right)-g\right.}=$ NZD 150901

Meanwhile, owner-occupiers cannot deduct mortgage interest payments but face no tax on imputed rents or capital gains. These provisions push up the property valuation by $9 \%$ for a mortgaged buyer, and by over $100 \%$ for the unmortgaged owner-occupier:

Mortgaged owner-occupier value:

$$
V=\frac{A}{0.8 i+f+0.2 r\left(1-t^{c}\right)-g}=\text { NZD } 108858
$$

Unmortgaged owner-occupier value:

$$
V=\frac{A}{r\left(1-t^{c}\right)+f-g} \quad=\text { NZD } 206799
$$

This simplified scenario indicates that purchasing a property with a mortgage is most advantageous for rental property

claimed separate (higher) depreciation rates for different parts of the building (e.g. wiring, plumbing), which in principle should have then slowed the depreciation rate of the building itself. 
investors, whereas unmortgaged owner-occupiers eventually enjoy the largest benefits from the tax system. Owner-occupiers therefore have the incentive to pay down their debt as quickly as possible. These tax benefits are highest for buyers in the top marginal tax bracket and increase substantially with the amount of capital gains.

Overall, the tax incentives to own property may have led to a larger concentration of household portfolios in property and less in financial instruments than would otherwise be the case, distorting the allocation of economic resources. In New Zealand, the average size of new houses has increased from 136 square metres in 1991 to 197 square metres in 2009, despite the shrinking size of households from an average of 2.8 people to 2.6 over this same period (Figure 8 ). Tax benefits also increase with income and are thus regressive. House price increases redistribute income from new entrants in the housing markets to existing homeowners (Andrews et al., 2011) and lead to a growing market segment that cannot afford to buy a home. Indeed, widening inequalities in the distribution of net worth have been observed across New Zealand households. Estimates by Le et al. (2010) based on data from the 2007 Survey of Family, Income and Employment (SoFIE) $)^{9}$ suggest that the wealthiest $20 \%$ of the population owns $70 \%$ of the total net worth (of which property is the most important component), while the poorest $30 \%$ have almost no net wealth. Based on assets net of liabilities, Le et al. (2010) find that New Zealand's Gini coefficient for net worth was closer to 0.7 in 2006, significantly higher than the official income-based measure of 0.34 . To help address rising affordability problems the government has introduced several programmes to assist low- to moderate-income households to access home ownership (Box 2).

\section{Box 2. Government assistance with home ownership}

The government provides various programmes to assist low- and moderate- income households to purchase their first home.

Welcome Home Loan: an initiative introduced in 2003 to make access to home ownership finance easier for modest-income New Zealanders. Loans of up to NZD 350000 are provided by participating institutions to those who can afford mortgage repayments but not a large deposit for a first home. Participating lenders determine the criteria and terms of the loans, while Housing New Zealand Corporation (HNZC) provides them with insurance against loan loss. Eligibility is limited to those with an annual before-tax income of no more than NZD 85000 (or NZD 120000 for three-or-more-person households) with a good credit rating and who plan to live in the dwelling. Since 2003, almost 6000 households have benefited from Welcome Home Loans.

KiwiSaver: administered by HNZC, began in July 2007. Assists first-time home ownership for those who have been members longer than three years and plan to live in the residence through two channels:

- $\quad$ Allowing withdrawals of all personal and employer contributions and all returns to purchase a first home;

- $\quad$ Providing a first-home down payment subsidy of NZD 3000 - NZD 5000 for those with combined before-tax income less than NZD 100000 (for one- to two-person households).

Gateway Housing: makes Crown land available to first-time buyers with payment for the land deferred and capped for 10 years. Gateway Housing opportunities are available primarily through partnerships with community housing organisations and HNZC.

Kainga Whenua: introduced in February 2010, enables those with a license to occupy Māori land to obtain a loan of up to NZD 200000 to build, purchase or relocate a house there. Eligibility is based on the same income criteria as for Welcome Home Loans.

Housing Innovation Fund: provides community housing providers and Iwi/Māori organisations with funding to build or

9. This is a longitudinal survey conducted by Statistics New Zealand which started in October 2002 and was to have been run annually for eight years. The estimates in Le et al. (2010) are based on the 2004 and 2006 waves. 
buy community rental housing and to provide for affordable home-ownership opportunities through either a term loan or a grant.

\section{The government has been trying to reduce these distortions}

The government fully recognises the distortions arising from New Zealand's tax treatment of housing, and the 2010-11 budget included several measures to reduce them. One was the removal of the ability to deduct property investment losses from taxable income in the calculation of Working for Families tax credits. Regulations on LAQCs were also tightened, so as to no longer permit the attribution of losses to shareholders, with the option to convert LAQCs to "look-through companies" in which the personal income tax rate applies to both profits and loss deductions. The budget further eliminated the ability to claim depreciation allowances on most residential and commercial properties. ${ }^{10}$

The 2010-11 budget also reduced the top income tax rate from $38 \%$ to $33 \%$, which lowered the incentives for high-income earners to claim rebates for losses on investment properties. This change also lowers the tax on interest income, making interest-bearing assets more attractive relative to housing. Another reform was the reduction in the top tax rate for most portfolio investment entities (PIEs) from $30 \%$ to $28 \%$, which increases the attractiveness of these savings vehicles relative to housing. Finally, funding was increased for Inland Revenue to enforce tax compliance, particularly on property investments believed to be used for tax avoidance. Together, these tax changes should raise the cost of rental property investments somewhat relative to alternatives, while possibly driving rent levels higher.

\section{Yet further measures are needed}

Although these reforms are welcome, some tax bias favouring housing remains because of the absence of taxes on capital gains and imputed rent. In the 2010 ANZ Property Investment Survey (ANZ, 2010), 70\% of property investors reported that the 2010-11 budget did not change their investment strategies. While many other countries also exempt owner-occupied housing from taxes on capital gains or imputed rent, they often offset the bias by granting tax advantages to other savings vehicles (in particular private pensions). New Zealand's experience suggests that policies that divert private savings towards housing at the expense of other assets contribute to raising the cost of capital and limiting the depth of its financial markets (CMD Task Force, 2009). An under-developed financial system in turn reduces the ability of the economy to allocate capital towards its most productive uses, hindering business investment and productivity. These consequences suggest that eliminating the bias towards housing relative to alternative savings vehicles could enhance the productive capacity of the economy at large. The availability of KiwiSaver since mid-2007 should help NZ households diversify their savings, and, given its tax-favoured status, should have made non-housing investments relatively more attractive. However, the explicit home ownership subsidy (Box 2) it provides to members undermines the asset diversification process.

The persistent imbalances in residential property markets suggest a need to remove the incentives inherent in the tax system that divert household savings towards housing. Removing the distortion between housing and other investments would ideally involve taxing housing income in the same way as other capital income and thus introducing a comprehensive tax on capital gains and imputed rents. This section

10. These were removed on buildings with estimated useful lives of at least 50 years. Hence, "short-lived" structures remain eligible for depreciation allowances, provided that the owner can demonstrate the case for such treatment. 
discusses the practical issues surrounding the implementation of these taxes and the potential alternatives to address these difficulties.

\section{A tax on capital gains}

While the absence of a capital gains tax favours both property and shares, it has probably generated a greater bias towards housing and farm assets because of external factors that make equity investments less attractive in New Zealand. These factors include the country's lack of deep stock markets and the greater ability to leverage on property investments, neither of which would be addressed by a capital gains tax. Nonetheless, taxing capital gains on an accruals basis would broaden the tax base and reduce distortions in investment decisions. However, several practical and political challenges have prevented the government from proceeding in this direction. One is the equity and fairness issues arising from its effect on asset-rich but cash-poor households. Such a tax could create liquidity problems for households living in areas where property values have appreciated dramatically, but with insufficient cash-flow to cover the tax burden (OECD, 2006). Additionally, the tax could be perceived as unfairly treating retired households who do not plan to move and would thus receive no benefit from the appreciation of their properties. As a result, most countries that tax capital gains do so on a realisation basis, with the taxation deferred until the year of asset disposition or the death of the owner.

Another key hurdle to introducing a capital gains tax is that it could result in an immediate decline in land or property values by the amount of the rise in the net present value of future tax liabilities, thus acting as a lump-sum tax on existing owners (Coleman and Grimes, 2009). Given the importance of property and farmland in both household and bank balance sheets, any substantial decline in values could have repercussions for the wider economy and financial system. However, the introductions of capital gains taxes in Australia (1985) and in Canada (1972) did not have any noticeable immediate impact on aggregate house prices.

A realisation-based capital gains tax would need to be carefully designed to avoid introducing other distortions, namely "lock-in" effects leading to sub-optimal decisions over asset sales. Investors may be motivated to defer the sale of appreciated assets with good prospects, and conversely, to bring forward the sale of those that are depreciating. Although studies find that such effects do not tend to be significant (Burman and White, 2003), most countries put in place provisions to reduce their associated inefficiencies (Annex 2.A1). These include taxing only part of the capital gains, applying a reduced statutory tax rate or allowing exemptions for capital gains either below a minimum threshold or beyond a certain holding period. Allowing roll-over relief for principal residences is another common provision, which exempts the capital gains from tax when the sale proceeds are re-invested in a similar asset. The incentive to bring forward capital losses is commonly mitigated by ring-fencing, which allows capital losses to be offset only against current or future capital gains for tax purposes, and not other forms of income. A potential drawback to such an approach is that it may discourage risk-taking in certain cases, although the relevant evidence is mixed (OECD, 2006). An indexation allowance that exempts capital gains arising from inflation would better approximate taxation of real economic income, while lessening lock-in effects (NZ Treasury and IRD, 2009). This would need to be accompanied by an indexation of interest income, which is currently taxed on a nominal basis, in order to avoid tax-planning incentives. Furthermore, introducing a capital gains tax may entail reinstating the allowance for depreciation expenses, which was removed in the $2010-11$ budget. $^{11}$

11. This would allow for more symmetric tax treatment of capital appreciations and depreciations and would require distinguishing the tax treatment of undeveloped land from that of the building (the "improvement" component of NZ's property valuation system). While land generally appreciates in value, the depreciation of the building would be deducted from the cost base used to calculate taxable capital gains. 
Incorporating such design features into a capital gains tax inevitably raises the complexity of the tax system. Many countries allow exemptions for the primary residence (see Annex), which could facilitate public acceptance but at the expense of shifting even greater tax advantage onto owner-occupied housing relative to other assets. Nevertheless, even a tax that partially exempts capital gains on principal dwellings could still effectively reduce the bias towards property investment. To the extent that a capital gains tax is not implemented, some alternative options to reduce tax incentives for housing include increasing the tax advantages of alternative saving vehicles and limiting the tax deductibility of rental property losses. As second best approaches, however, these alternative options may alleviate current distortions in the system at the cost of moving further away from neutrality or introducing other distortions.

\section{Reduce taxation of alternative savings vehicles}

In the absence of a capital gains tax, the bias towards property investment could alternatively be reduced by improving the tax incentives to invest in other savings vehicles. The extent to which households invest excessively in housing as a means of retirement provision may reflect the way private pensions are taxed. The current taxation of savings is based on a taxed-taxed-exempt (TTE) system, which taxes income from labour and investment when earned, but not when investment assets are sold or drawn down. Most other countries operate at least partial exempt-exempt-taxed (EET) systems, which exempt labour income that is saved, as well as returns from investing that income, but taxes the income when it is withdrawn from the investment vehicle. This tends to favour long-term saving to the extent that it is mainly withdrawn during retirement when income levels and thus tax rates are lower. Since the TTE tax system effectively imposes a tax on the returns from saving, introducing EET savings vehicles would remove the relative advantages that exist for housing investment. The government has moved somewhat in this direction by taxing returns on certain types of saving at lower rates, namely capital income earned within PIEs such as KiwiSaver, unit trusts and superannuation funds. In the 2010-11 budget, the tax rate on returns within these vehicles was lowered relative to marginal tax rates for investors in most income brackets. However, some potential implications should be considered. Reducing the tax rate on saving may require raising taxes elsewhere to offset the revenue loss, which may have efficiency costs. Furthermore, while imposing caps on the amount that can be saved at the preferential tax rates may limit the increase in private saving, the fiscal cost needs to be minimised in order to improve national saving overall.

\section{Limit the tax-deductibility of losses on property investments}

Distortions in the rental property market could be targeted directly by reforming the tax treatment of income and losses arising from rental property investments. This could be achieved by limiting the extent to which losses can be deducted from taxable labour income, for example via ring-fencing. In particular, the United Kingdom allows rental property losses to be deducted only against profits from other properties, or to be brought forward to offset future rental income, whereas the United States permits such deductions only up to a certain income ceiling. Additionally, rental properties could be treated as separate investment entities and subjected to a flat tax rate, as currently applies to trusts or superannuation funds. This would eliminate the existing regressivity that arises from the ability to deduct losses at the marginal income tax rate.

\section{A tax on imputed rent, property or land}

The economic rationale for taxing imputed rents is that owner-occupied housing represents an advantage in the sense that disposable income is boosted by the amount of rent that does not need to be paid. This imputed rent can also be seen as a return on private investment in real estate (Frick and Grabka, 2003). Many countries do not tax imputed rental income due to the high administrative and compliance costs of measuring it accurately (OECD, 2010a). In these circumstances, denying mortgage interest deductibility and imposing property taxes can act as a second best approach to counteract the 
resulting bias towards housing investment (Johansson et al., 2008). Furthermore, Coleman (2009) finds that in the absence of a capital gains tax, a property tax can act as a good substitute in producing similar effects on welfare, rents, prices and home ownership rates. ${ }^{12}$

New Zealand already denies mortgage interest deductibility to owner-occupiers and collects property taxes from homeowners in the form of local "rates". These rates are administered by local governments and thus vary by jurisdiction. Altogether they account for almost $60 \%$ of local government revenue and fund the bulk of their spending on public services such as roads, pipes and sewerage networks. Local property tax revenues averaged $2 \%$ of GDP as of 2008, roughly on par with the OECD average but have declined as a percentage of housing values from $2.2 \%$ in 1980 to $0.65 \%$ in 2008 (Figure 12).

Figure 12. NZ average local property taxes

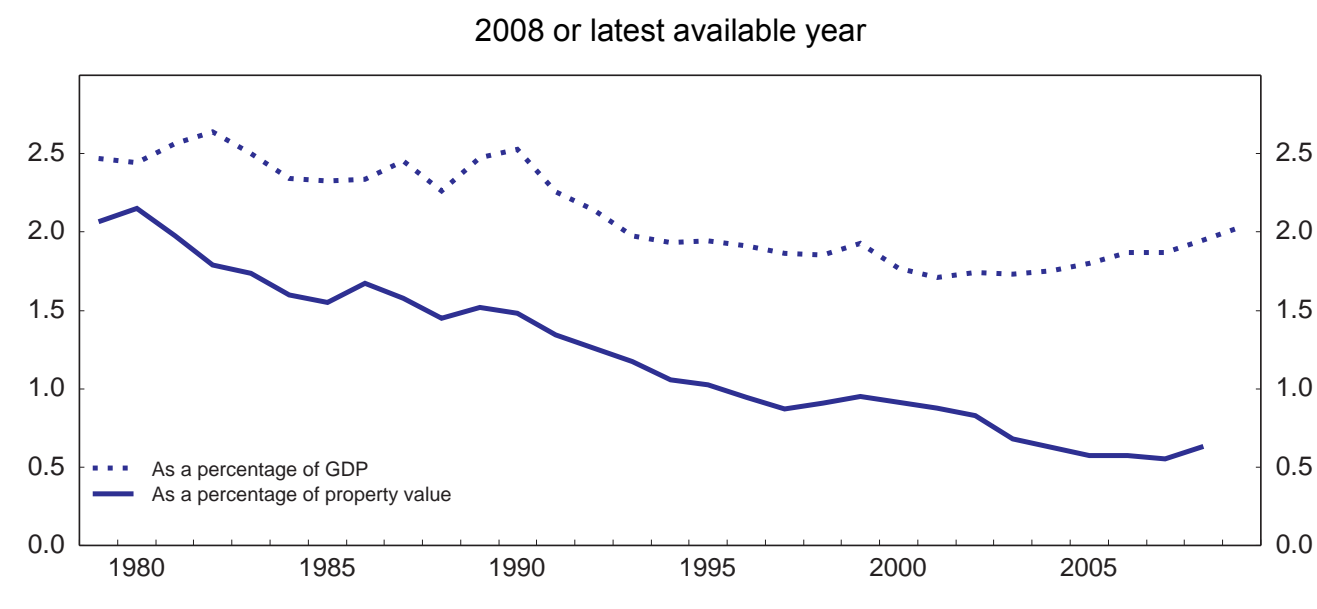

Source: IBFD (2009), Reserve Bank of New Zealand and OECD calculations.

As in the case of capital gains taxes, distributional and fairness considerations can pose obstacles to increasing property taxes, since property values do not necessarily indicate ability to pay. Tax rates are also differentiated across residential, commercial and rural properties, to a large extent to adjust its incidence across different taxpaying groups, usually in favour of rural and residential properties. However, the result of increasing use of differential rates and fixed charges is that the rating system has become more regressive, and there is considerable public misunderstanding about how it works (Local Government Rates Inquiry Panel, 2007). These features have probably contributed to growing public resistance towards increasing local property taxes. In general, these issues can be addressed by designing the tax to be progressive or providing subsidies to low-income households (OECD, 2010a). For example, the property tax rate applied could be made dependent on personal income tax rates, allowing a closer approximation to a tax on imputed rents. Indeed, a rebate scheme is in place for low-income households in New Zealand, and some local authorities address cash-flow problems by allowing rate payments to be postponed until the property is sold or until the owner's death.

Currently, property values are assessed by local councils every three years and given a Council Rating Value, which comprises a land value (value of undeveloped land), capital value (value at the date of the previous valuation), and the value of improvements (the difference between capital and land values). In the past, the majority of the 74 local authorities set rates based on land value, but over time most have shifted towards using capital values, because they are perceived to better reflect ability to pay

12. This finding assumes a flat-rate property tax and is conditional on inflation remaining low and stable. 
(McCluskey et al., 2006). ${ }^{13}$ Meanwhile, the bulk of the increase in property values reflects rising values of land, rather than improvements (Grimes and Aitken, 2006), suggesting that land values may be the appropriate basis for the tax.

A land tax would tend to be more efficient than a property tax. Because land is fixed in supply, it is relatively price-inelastic, and therefore deadweight losses from taxing it are relatively low. There are also indications that a land tax would be more progressive than a property tax in New Zealand, since people with higher income tend to live on more valuable land (Coleman and Grimes, 2009; Kerr et al., 2004). Such a tax would offer the additional advantages of a broad base and relatively easy administration, given the existing local government rating system. A challenge posed by the land tax, however, is that it would disproportionately affect owners of land-intensive properties such as farmers, forestry owners and Māori communities. Since such landowners tend to have low per hectare land value, this issue could be addressed by taxing land on the basis of value per hectare (Coleman and Grimes, 2009).

Raising such a tax could immediately lower land and property values by the amount of the increase in discounted future tax liabilities, but these shocks could be minimised via grandfathering the current treatment of existing owners. Another drawback to a property or land tax is that it would fail to address the aforementioned distortions in rental property markets, since the 2007 Income Tax Act would allow the expense to be deducted from taxable income. In general, this Act allows the deductibility of most expenses incurred for the purpose of deriving assessable income, with the exception of depreciation (and that only since the 2010-11 budget). ${ }^{14}$ Nonetheless, such a tax would reduce the economic benefits to owner-occupiers arising from untaxed imputed rents.

\section{Eliminate untargeted home ownership subsidies}

The lower tax rate on income earned within PIEs such as KiwiSaver enhances incentives to diversify household portfolios using these vehicles. However, this effect is counteracted by the option for all KiwiSaver members (of longer than three years) to withdraw all personal and employer contributions, as well as all returns, to purchase a first home. Since returns are taxed at a lower rate and employer contributions are both compulsory and tax-deductible, such withdrawals effectively subsidise employed individuals' home ownership. Furthermore, the subsidy is provided to all members regardless of income level. Tax-free withdrawals should therefore be treated as interest-bearing loans or limited to low-income members.

\section{The social housing sector}

The government helps low-income families to access affordable housing through subsidies as well as social dwellings, based on various income and needs criteria. Almost one-quarter of all households receives some form of government support, of whom one-sixth live in public housing. Most support is administered through the national crown agency, Housing New Zealand Corporation (HNZC), although some public dwellings are provided by local governments as well. The current government's objective for social housing is to "provide cost-effective state housing and associated services to those most in need, for the duration of their need" (Housing New Zealand Corporation, 2010). This section discusses some options to improve the effectiveness of this model of social housing provision.

13. As exceptions, two local authorities set rates based on an annual value, which is the greater of $i$ ) the estimated gross annual rental less $20 \%$ (or $10 \%$ for vacant land) or $i i$ ) $5 \%$ of the property's capital value.

14. This includes expenses arising from mortgage interest, insurance, bank fees, advertising, repairs and maintenance, travel costs, solicitor fees and property management. 
Almost $70 \%$ of government expenditure on social housing assistance is distributed as subsidies to people living in private accommodation. This Accommodation Supplement (AS) is provided through the Ministry of Social Development to those who meet certain income criteria. The subsidy covers $70 \%$ of the recipient's weekly cost minus an entry threshold, which can be used to offset some of the cost of board, rent or mortgage payments. The amount received is subject to a regional maximum. More than half of private renters receive the AS, and $4 \%$ of homeowners use it to reduce the burden of mortgage payments, for a total of about 330000 individuals. Despite a fairly constant number of AS recipients between 2000 and 2008, spending on the AS increased by an average of $4.7 \%$ per year, reflecting an increase in housing costs (HSA Group, 2010). The recession then led to an almost $20 \%$ jump in the number of AS recipients in 2009 , with a corresponding hike in spending.

An additional 67700 households live in a state dwelling, accounting for roughly $15 \%$ of all recipients of social housing assistance. Eligibility to live in a social dwelling is determined based on needs, level of income and wealth, and residency status. Priority is determined by risk levels faced by candidate households with respect to affordability, adequacy, suitability, accessibility and sustainability. New vacancies are allocated by matching housing with applicants' requirements, with priority given to those with the highest risk. Among the households who live in a HNZC dwelling, 89\% pay a below-market, income-related rent (IRR). The IRR is set at $25 \%$ of the tenant's net income up to the NZ Superannuation threshold, after which half of every dollar earned is charged until the market rent is reached. The market rent for each state dwelling is set based on a benchmark for private rental accommodations in the proximity of the building. Eligibility for income-related rent assistance is reassessed when circumstances change, and $11 \%$ of social tenants pay the market rent or close to it. The average length of tenancy in a given state dwelling is 7.8 years. This compares with a national median of 2.0 years spent in the same residence for private renters, and 6.3 years for owner occupiers (based on the 2006 census). This lock-in effect is one of the most costly features of social housing provision, as the reduced mobility can harm re-employment prospects in the event of a negative local labour-market shock.

In early 2010, the government-appointed Housing Shareholders Advisory Group published a report (HSA Group, 2010) advising on measures to improve the effectiveness and efficiency of the social housing sector. The government has since accepted a number of its recommendations, including an increasing focus on helping those with priority housing needs and introducing reviewable tenancies for all new state housing tenants from July 2011. Until now, tenants' eligibilities have never been re-assessed, and a number have therefore remained in the same dwelling over the long term, even if their household size has shrunk or they could afford market rents. The perception that state dwellings offer a "lease for life" reduces the capacity to deliver housing to those most in need and may also distort the private housing market. While the new policy is therefore a welcome step, introducing regular needs re-assessments for all existing tenants would further improve the ability of the available supply to match household needs. For example, at end-2009 almost $4 \%$ of state dwellings were being underutilised by two or more bedrooms, while a similar share were overcrowded (HSA Group, 2010).

The targeting of higher-need households has increasingly concentrated socio-economically disadvantaged groups in certain areas (Housing New Zealand Corporation, 2010), which may create adverse neighbourhood effects in the form of depressed educational and health outcomes or access to services. Moving towards terminating state rental contracts for those whose eligibility has changed may further reinforce residential segregation and social exclusion, while possibly aggravating work-disincentive effects for tenants. The introduction of the Tenant Home Ownership programme in June 2009 should help limit these effects, as it enables occupants who are able to secure mortgage financing to purchase their dwelling outright from the state. Introducing regular tenancy re-assessments would need to be accompanied by assistance in securing new housing for those evaluated to be no longer in need, as well as increased efforts to actively assist all tenants to achieve financial independence and self-sufficiency. The HNZC may also wish to consider whether certain tenants requiring more permanent housing provision, 
such as the elderly and seriously disabled, may benefit more from financial assistance for placement in specialised facilities that can better cater to their needs. Meanwhile, the ability to transition other tenants into self-sufficiency will depend on the availability of affordable housing in the private market, which has become increasingly squeezed by rising property prices.

Inflexibility in the supply of social housing has resulted in lengthening high-priority waiting lists in certain regions, in contrast with an oversupply of social housing in others with low demand, with a potential net shortage of over 10000 units (HSA Group, 2010). As of mid-2010, over $60 \%$ of priority applicants were waiting for housing in Auckland, where only 44\% of HNZC properties are situated. These misalignments are expected to be addressed over time through an asset management strategy. Supply has traditionally been entirely publicly funded and therefore constrained by state finances. Recently announced intentions to begin exploring partnerships with non-profit providers and private-sector builders should help HNZC to improve its capacity to expand the supply of affordable housing more efficiently in the future.

Rising property values have placed increasing financial pressures on the social housing sector. The government compensates HNZC for the difference in rent paid by tenants and the market rent on the property through an IRR subsidy. Between 2000 and 2008, the cost of the IRR subsidy increased by an average of $6.2 \%$ annually, reflecting the faster growth of market rents relative to social housing tenant incomes. The average cost per recipient of an IRR subsidy in 2008-09 was almost NZD 8500 a year, more than double that spent annually per AS beneficiary. Furthermore, the sum of rents paid and IRR subsidies does not sufficiently cover HNZC's operating expenses. This is because it tends to face higher costs than the average private landlord, related to subsidised water rates, higher maintenance expenses due to the age and condition of state dwellings, and delivery of various other programmes such as community renewal, energy-efficiency retrofits and housing policy research. To improve long-term financial viability, the HNZC should discontinue water rate subsidies to those paying market rent and consider divesting non-core activities and programmes that overlap with the functions of other government departments. A more targeted focus may result in improved alignment of the needs of low-income households with services provided, as well as efficiency gains.

\section{Reducing supply rigidities}

An important factor in the proper functioning of housing markets is the extent and speed with which housing supply responds to changes in prices. The supply elasticity determines the degree to which demand shocks materialise into changes in house prices. Moreover, an insufficient supply of new housing may have wider implications for the economy by boosting expectations of future house-price increases and driving speculative activity that pushes prices above fundamental levels (Barker, 2008). The speed at which new housing construction adjusts to demand depends on several factors, including the degree of land scarcity and competition in the residential construction industry, the restrictiveness of land-use planning policy, the availability of skilled trade workers and the state of infrastructure. At the aggregate level, New Zealand's housing supply appears to respond reasonably well to changes in house prices over the long run relative to other OECD countries, but demand shocks nevertheless tend to have persistent effects on the level of house prices (Box 3).

Supply elasticities vary considerably across regions, reflecting differences in land-price movements as well as regulatory constraints (Grimes and Liang, 2007). Factors that push up land prices may stifle new housing construction by squeezing the potential profits of developers (Grimes and Aitken, 2006). Alternatively, they may shift new housing supply towards multi-unit apartment buildings, which are less land-intensive than detached dwellings, as has occurred in Auckland.

The planning system that regulates housing supply is fairly complex and is framed by three pieces of legislation that govern different aspects of land development. The Resource Management Act 1991 (RMA) 
provides the framework for promoting the sustainable management of natural resources and addresses land-use development based on its effects on the environment. Implementation of the RMA generally takes the form of designations and zoning designed to manage environmental effects. The Local Government Act 2002 (LGA) provides guidance for local councils' infrastructure and investment plans, and the Land Transport Management Act 2003 (LTMA) outlines the system for national and regional transport strategy, planning and funding. In addition to the regulatory constraints on land use, the Building Act 2004 governs design and construction practices. Regional and local governments use these laws as guidelines to develop different economic development strategies, with district plans implemented at the local council level. The restrictiveness of land-use regulations within regional development strategies constrains housing supply in these regions.

\section{Box 3. Estimates of housing supply responsiveness}

Recent work by the OECD (Caldera Sánchez and Johansson, 2011) derives housing supply and demand elasticities over the short and long run across 21 OECD countries by jointly estimating equations for real house prices and real residential investment. The results suggest that the factors that determine long-run housing supply in New Zealand are the levels of real house prices and real construction costs (Table 2). In the long term, residential investment adjusts to price signals on a similar scale as the average elasticity across the 21 OECD countries, but the short-run supply response is large relative to elsewhere. Population changes do not appear to significantly influence the housing supply in the short or long run, but this may reflect their correlation with house prices: increases in the population appear to have significantly larger-than-average effects on house prices in the long term, which points to supply rigidities.

Table 2. Long-run and short-run elasticities

\begin{tabular}{|c|c|c|c|c|c|}
\hline & $\begin{array}{c}\mathrm{NZ} \\
\text { coefficient }\end{array}$ & $\begin{array}{l}\text { Average } \\
\text { OECD }\end{array}$ & & $\begin{array}{c}\mathrm{NZ} \\
\text { coefficient }\end{array}$ & $\begin{array}{l}\text { Average } \\
\text { OECD }\end{array}$ \\
\hline $\begin{array}{l}\text { Long-run house price } \\
\text { determinants }\end{array}$ & & & $\begin{array}{l}\text { Long-run housing supply } \\
\text { determinants }\end{array}$ & & \\
\hline Income & $0.9^{*}$ & 2.0 & Lagged real house price & $0.7^{*}$ & 0.7 \\
\hline Dwelling stock & $-15.2^{*}$ & -4.3 & Lagged real construction cost & $-1.0^{*}$ & -0.2 \\
\hline Interest rate & 0.2 & -0.4 & Population & 0.5 & 3.4 \\
\hline Population & $24.2^{*}$ & 6.9 & Constant & $19.5^{*}$ & - \\
\hline Constant & $-108.6^{*}$ & - & & & \\
\hline $\begin{array}{l}\text { Short-run house price } \\
\text { determinants }\end{array}$ & & & $\begin{array}{l}\text { Short-run housing supply } \\
\text { determinants }\end{array}$ & & \\
\hline Income growth & $0.5^{*}$ & 0.3 & Lagged real house price growth & $1.4^{*}$ & 0.5 \\
\hline Dwelling stock growth & -0.3 & -0.7 & Lagged real construction cost growth & 0.2 & 0.1 \\
\hline Interest rate change & 0.1 & 0.0 & Population growth & 24.2 & 1.7 \\
\hline Population growth & $13.9^{*}$ & 7.6 & & & \\
\hline Speed of Adjustment & $-0.1^{*}$ & -0.1 & Speed of Adjustment & $-0.4^{*}$ & -0.2 \\
\hline Estimation period & 94Q3-07Q4 & - & Estimation Period & 94Q3-07Q4 & - \\
\hline
\end{tabular}

1. Equations are estimated jointly using a seemingly unrelated regression model. * denotes statistical significance at the $10 \%$ level or more. Average OECD coefficients are unweighted averages of significant coefficients, with insignificant coefficients assumed to be zero.

Source: Caldera Sánchez and Johansson (2011).

The results also indicate that increasing construction costs tend to restrain residential investment in the long run more in New Zealand than in other countries. This finding may reflect low productivity in the construction sector compared to other countries, as well as declining labour productivity in this industry over time (Building and Construction Sector Productivity Taskforce, 2009). One potential reason for poor productivity performance is that the geographical dispersion of local markets tends to raise unit costs for most construction materials relative to other countries. High transport costs thus result in more separated plants of a smaller scale and less local competition (Page, 2009). Other possible factors identified by the Taskforce include a shortage of skills, low innovation and inefficient regulation.

Applying these estimated supply elasticities and extrapolating to the end of 2009 would suggest that real residential investment increased substantially above long-run "equilibrium" levels during the first years of the housing 
boom but have fallen well below since prices peaked in 2007 (Figure 13). The reasons for this supply contraction are not entirely clear, but it may indicate that demand conditions have been weaker than suggested by currently high price levels. Constrained credit conditions and heightened uncertainties faced by property developers since the global financial crisis may have also played a role, as these factors are not taken into account in the equations.

Figure 13. Supply has fallen below long-run levels

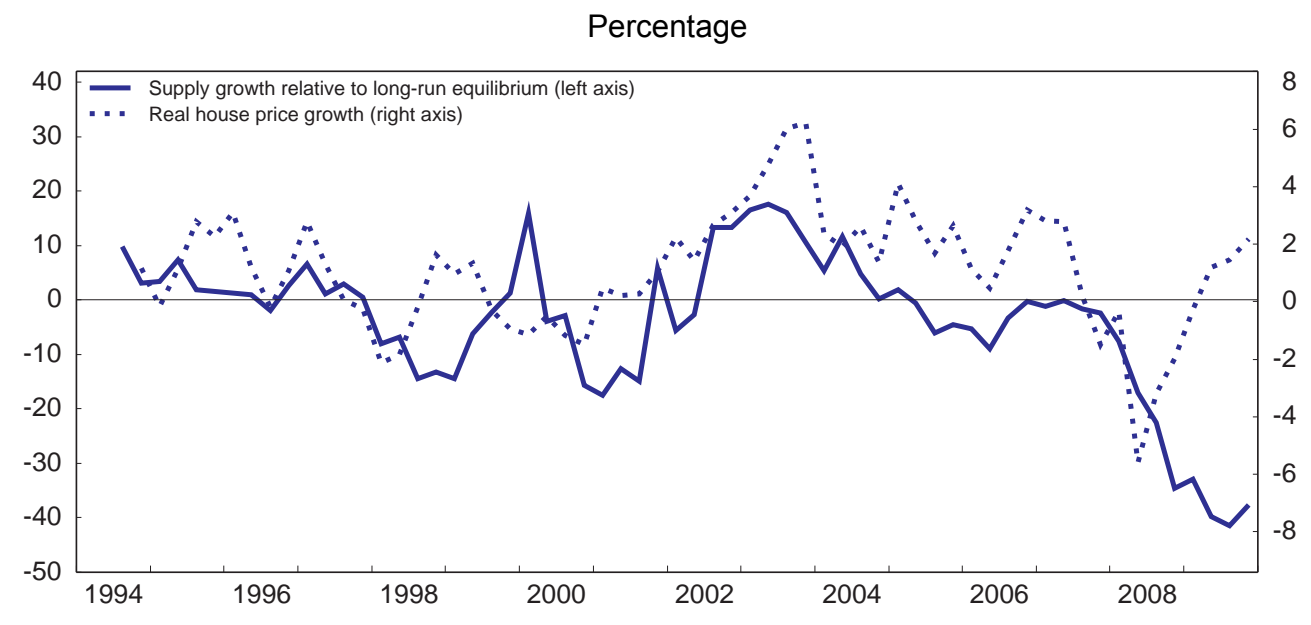

Source: Statistics New Zealand, QVNZ, OECD calculations.

Planning is important because land use generates externalities to the wider community, ecosystems and the environment that are not factored into the market price. For example, land can serve as a public good by providing open space for communities or by naturally regulating water flow to avoid flooding of downstream properties (Foresight, 2010). Policies should thus aim to integrate such benefits into the value of the land by evaluating all alternative uses and considering where these services would ideally be placed with respect to the location of residences and businesses. Price mechanisms that assign a socially optimal value to land allow the best uses to be realised and are more efficient than regulation (Foresight, 2010). Such values can be estimated in various ways, but in any case this is a complex task and subject to large uncertainties over the long-term impact of marginal developments on the environment and overall social welfare. Proper estimation of costs and benefits is particularly important for assessing changes in land use that are irreversible. Assuming these valuations can be reasonably estimated, pricing land development to reflect the marginal social cost incurred would lead to a more efficient planning framework than imposing regulation. It is probable that current zoning restrictions already reflect local councils' evaluations of optimal land use, but incorporating pricing mechanisms would ensure that private-sector incentives are aligned for development. Nonetheless, in cases where social costs cannot be accurately estimated, it may be practical to retain some form of zoning regulation.

Pricing mechanisms to capture the cost of land development are currently used by local councils in two different forms: "financial contributions" and "development contributions". Financial contributions are levied by local governments (under the RMA) on parties intending to subdivide or increase existing land use to reflect the environmental costs of new development. However, in many cases they do not appear to be used to influence the location of development based on an evaluation of optimal land use. Instead, zoning restrictions continue to dictate where development can occur, with financial contributions charged at a fixed rate based on the type of development, while the revenues collected are used to remedy 
any adverse environmental effects that result. ${ }^{15}$ Development contributions are charged under the LGA to recover some of the future infrastructure costs of accommodating growth. By forcing developers to internalise the environmental externalities and share the cost of new infrastructure investment, these instruments can promote efficiency by preventing excessive development. Conversely, they may discourage worthwhile development if set too high.

\section{Land-use planning can be improved}

Development strategies differ greatly between major urban areas such as Auckland, Wellington and Christchurch, and regional cities like Hamilton and Tauranga. Regional cities generally accommodate growth through outward expansion, greenfield development and the conversion of farmland and rural lots to residential land (Fairgray, 2009). Meanwhile, major urban areas tend to promote growth through brownfield development and densification within existing urban boundaries, with limited outward expansion or greenfield development. In particular, this latter "compact city" approach has been adopted by Auckland's Regional Growth Strategy (1999) and Christchurch's Urban Development Strategy (2004).

Policies to promote compact cities have been implemented in many OECD countries to guide the location and timing of new urban development in order to minimise environmental impacts (OECD, 2010b). Studies show that urban areas that are denser may contribute to reducing energy consumption by shrinking vehicle travel distances (Kamal-Chaoui and Robert, 2009; SOLUTIONS, 2009). In general, public transportation is more cost efficient when origins and destinations are more densely concentrated rather than dispersed. Compact cities may also be desirable from an economic standpoint because of the productivity and efficiency gains from agglomeration. However, these benefits should be weighed against potential social costs from crowding, noise and reduced biodiversity. For instance, higher-density urban areas may harm biodiversity due to increased runoff from impermeable surfaces (SOLUTIONS, 2009). Furthermore, promoting higher-density development on its own is not sufficient to reduce carbon emissions and may even increase them if it leads to more congestion and slower travel speeds (Foresight, 2010). Travel distances can be reduced only if communities are designed to maximise connectivity with work, amenities, schools, community facilities and open space. This entails infrastructure that accommodates cycling, walking and strategic mass-transit linkages, integrated with a greater mixing of residential, commercial and community land uses (Kamal-Chaoui and Robert, 2009).

Regardless of urban form, planning policies will concord best with climate-change mitigation goals if they integrate residential development with public transit options and the location of jobs. The framework should also ensure that prices and incentives for land and road use are aligned with policy objectives. Charging a toll on urban commuters tends to increase the cost of road travel, creating incentives for residents to relocate into the city and thus shrinking its spatial size and raising population density (Brueckner, 2007). Although such tolls may encourage a relocation of some economic activities to fringe locations, thus expanding demand for land and travel distances (Quddus et al., 2007), appropriate pricing mechanisms that reflect the environmental cost of land development should mitigate these effects.

Re-evaluate urban growth boundaries

Auckland's Regional Growth Strategy (RGS) is often identified as a major culprit behind the region's dramatic land price increases. Adopted in 1999, the RGS aims to promote a compact city capable of accommodating at least two million inhabitants by 2050 while protecting rural and coastal environments.

15. For example, in Auckland all new residential developments are charged a fixed rate per dwelling unit (to be paid in cash or land), with revenues to be applied to expanding surrounding park space. Meanwhile, financial contributions from new business developments are used to address the resulting needs for additional signage or lighting, or pedestrian footpaths, etc. 
The council has pursued this objective through two main avenues. The first is to define explicit boundaries within which urban development is to be contained, known as the Metropolitan Urban Limits (MULs). The concept of urban boundaries was first introduced in Auckland over 50 years ago but has evolved over time and been increasingly enforced. The aim of the MULs is to control urban sprawl and limit adverse environmental effects on surrounding areas. The second element of the growth strategy involves intensifying development around multiple growth nodes and transport corridors, which has not progressed far due to a number of obstacles.

Urban growth boundaries have been adopted by a number of cities in the United States, the United Kingdom, Japan and Switzerland, with varying degrees of success (OECD, 2010b). On the one hand, a restricted area that is set too large may be ineffective for limiting urban sprawl. On the other hand, defining a perimeter that is too small may quickly drive up land and housing prices within the containment area. Indeed, Grimes and Liang (2007) find that, after controlling for other factors, Auckland's MULs have boosted land prices to 8 to 13 times the price of land outside the boundaries and that they have become an increasingly binding constraint on land supply over time. Furthermore, land just beyond the borders has also experienced large relative price increases because of speculation that the MULs will be expanded. There are indications that land price pressures have acted as a considerable constraint on housing supply in Auckland (Grimes et al., 2006), thus exacerbating housing-market imbalances and expectations of further price increases. Relative to rent levels, Auckland's house price increases have exceeded those of most other regions since 1992 (Figure 14), although not by a large margin. ${ }^{16}$ This small difference may reflect the use of restrictive zoning practices in other regions as well, and/or the fact that common macroeconomic factors have played an even larger role in driving up house prices across the country.

\section{Figure 14. Regional price-to-rent ratios}

Index $1992=100$

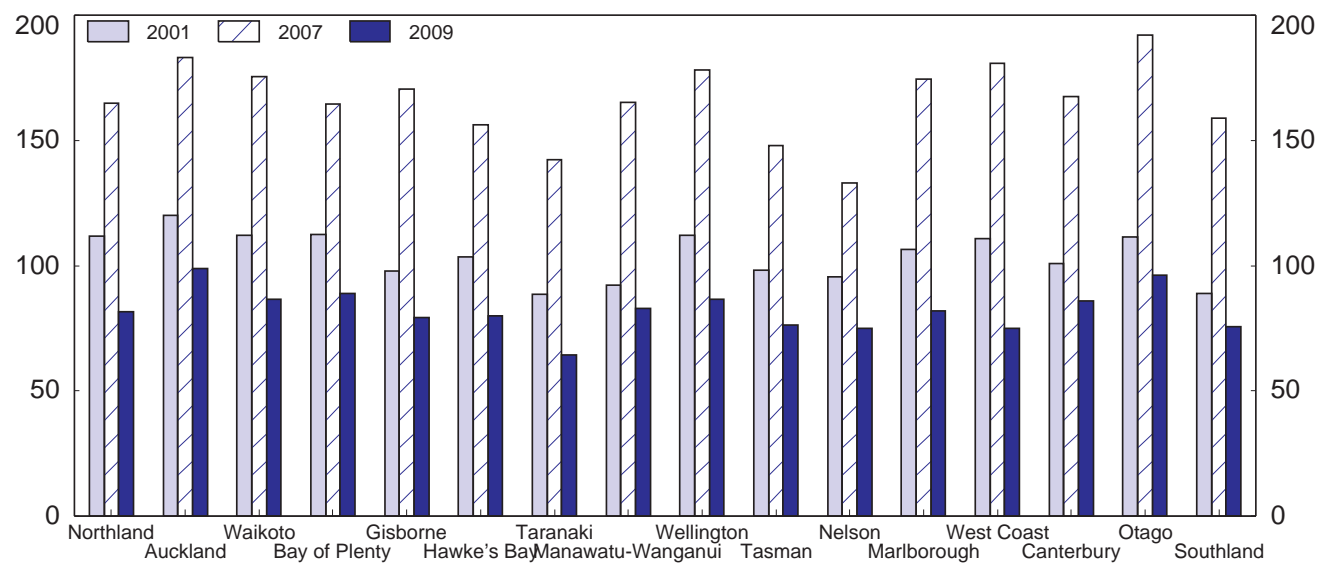

Source: QVNZ, Department of Building and Housing.

Thus far, the MULs have successfully controlled urban expansion to a large extent via infill, but these opportunities are being exhausted. Despite environmental objectives, considerable degradation has nonetheless occurred in the quality of water, air and open space (Hill, 2008). These costs suggest a more comprehensive analysis is needed of the MULs' social, economic and environmental implications (Ministry for the Environment, 2010). Urban growth boundaries are generally adjusted as needs evolve, in

16. Regional price-to-rent ratios are compared as a proxy for affordability, in the absence of regional data on household disposable income. In principle, rent levels would be expected to increase with land prices but may have been restrained by lower income growth among renters (relative to homeowners). 
most cases every 10-20 years (OECD, 2010b). As a tool to contain excessive urban expansion, studies show that urban growth boundaries act as a second best policy relative to levying a congestion toll on commuters, because they are far less effective in promoting densification within the area (Brueckner, 2007). Reduced carbon emissions could be achieved more efficiently through higher charges for road use and parking within the city, combined with substantial enhancements to mass transit service.

\section{Better integrate urban planning and development with transport and infrastructure policy}

A first evaluation of the RGS by the Auckland Regional Council (ARC, 2007) noted that residential densification was not occurring in the majority of growth centres and corridors that had been targeted for development. Furthermore, objectives to promote development within those growth nodes were often not being incorporated into district plans at the local council level. For example, a number of district zoning plans in central Auckland continue to designate building height restrictions and minimum car-park requirements that appear to contradict goals for densification. One major obstacle preventing the RGS from being implemented effectively at the local level appears to be uncertainty over how to consolidate guidelines from the three pieces of legislation governing land development, causing long delays in the approvals process for building permits.

As a whole, the current planning approach remains overly complex and fragmented because the three laws were not designed to work together as an integrated urban planning system (Ministry for the Environment, 2010). The current system requires development proposals to be broken down into environmental, infrastructure and economic components, which are then addressed separately by the relevant legislation (Ministry for the Environment, 2010). This has resulted in a failure to align regulation and funding to integrate transport with land use and economic development. Land-use planning has often been disconnected from infrastructure or transportation spending decisions, with a lack of co-ordinated infrastructure provision at the regional and local level (ARC, 2007).

The lack of certainty over whether the appropriate infrastructure will be installed to support new residential construction can pose insurmountable risks to private developers, impeding the delivery of housing. Greater use of public-private partnerships would help to provide more predictability and reduce risks to developers. Improved engagement is also needed among various levels of government, private-sector developers and infrastructure providers to ensure that the policies adopted are feasible, coherent, equitable and well understood. ${ }^{17}$ Current efforts to reform the RMA to better incorporate the needs of urban environments via an aligned framework for land, infrastructure and transport are therefore welcome. The recent replacement of the Auckland Regional Council and its seven district councils by one unitary body should also improve co-ordination, as should the current development of a "spatial" planning system. A spatial planning system sets out a strategic framework across sectors to guide future development and policy by inter alia improving investment certainty and providing guidance on the location and timing of future infrastructure, services and investment. Extending the principles of spatial planning would also benefit smaller, developing cities across the country, given that short-sighted urban planning decisions committed in the early stages of development can be difficult to reverse.

The new planning system should include a comprehensive framework to formalise the pricing of land based on alternative uses, with more systematic use of pricing instruments such as financial contributions to influence the location of development. For example, levies could be discounted or waived in areas situated along public transit routes to reflect the environmental benefits associated with reduced car dependency. Meanwhile, the use of development contributions to fund infrastructure investment could also

17. For example, the Auckland RGS was implemented without the endorsement by the central government or developers of the locations or economic feasibility of densification plans (Ministry for the Environment, 2010). 
be better designed to encourage worthwhile private-sector development. In their current form, the charges force developers to assume the long-run costs of infrastructure upfront when cash flow may be most constrained, rather than distributing them to the users over time (Ministry for the Environment, 2010). This has the effect of assigning a disproportionate share of infrastructure costs to new dwellings, thereby reducing their affordability, while subsidising existing residents (Fairgray, 2009). It may also discourage private-sector development where it is most beneficial. To address these issues, these levies could be set in consultation with developers and local communities to promote transparency and fairness, with payments allowed in instalments over time. The cost of infrastructure could be more evenly distributed by charging higher user fees to those benefiting from the services provided, perhaps through higher targeted local rates for property owners or parking fees in the area.

Another factor that may limit progress towards densification is that household preferences may continue to favour larger, detached dwelling units. This may in part reflect perceptions of poor-quality development and urban design of apartment buildings, which increase concerns and public resistance to higher-density housing types (ARC, 2007). One reason for this may be a lack of experience or design skills among developers of medium-to-high-density housing, given the traditional orientation towards low-density dwelling types. Incorporating guidelines for multi-unit developments into the Building Code could also help, detailing provisions for natural light, ventilation, noise insulation and storage space. Nonetheless, household attitudes and lifestyles are diverse, and planning policies will need to adapt to a range of density preferences. This may involve expanding energy generation from renewable sources more suitable to lower densities (such as ground-source heat pumps) or adopting technologies that facilitate intermodal transport links to reach more dispersed locations (Foresight, 2010).

\section{Box 4. Recommendations for the housing sector}

\section{Reduce tax distortions}

- Eliminate tax incentives that bias savings decisions towards housing investment by introducing a comprehensive tax on capital gains realised beyond the year of implementation, allowing rollover relief (until death) for primary residences to mitigate lock-in effects. Partial exemption of capital gains on primary residences may be considered as a second best approach if it facilitates public acceptance of the tax. In the event that a capital gains tax is deemed politically infeasible, consider the following alternative options:

- Limit the tax-deductibility of losses from rental property investments by allowing them to be offset only against future rental income. Consider taxing such investments at a separate flat-rate tax to reduce regressivity.

- Further reduce the taxation of returns earned on alternative savings vehicles.

- To offset the distortions from untaxed imputed rents, consider introducing a property or land tax based on the land value per hectare, where the rate levied is scaled by the owner's marginal personal income tax rate. Remove local rate differentials across residential, commercial and rural properties.

- Modify KiwiSaver such that withdrawals for first-home purchases are treated as interest-bearing loans or limited to low-income members.

Improve ability of social housing to reach those most in need

- Begin regular tenancy re-assessments for all occupants of state housing, accompanied by increased efforts to assist all tenants to secure new dwelling options and achieve financial independence and self-sufficiency.

- Evaluate whether those requiring more permanent housing provision such as the elderly and seriously disabled may benefit more from financial assistance for placement in specialised long-term housing facilities better able to cater to their needs.

- To improve long-term financial viability, remove water rate subsidies to tenants paying market rents. Consider outsourcing non-core activities that may be more efficiently delivered by NGOs. Improve the 
ECO/WKP(2011)47

capacity to expand the supply of affordable housing more efficiently through partnerships with non-profit providers and private-sector developers.

\section{Reduce supply rigidities within the limits of environmental objectives}

- $\quad$ Adopt spatial planning systems for all urban areas to improve alignment of regulation and funding to better integrate strategies for land use, economic development, transport and infrastructure. Reform the RMA to better incorporate urban development needs.

- Increase engagement among various levels of government, private-sector developers and infrastructure providers to reduce uncertainties and hold-ups that have delayed the delivery of housing supply.

- Re-evaluate Metropolitan Urban Limits to ensure a proper assessment of social, economic and environmental costs and benefits. Undertake a comprehensive framework to value land based on formal cost-benefit analyses of alternative uses, considering all environmental, social and economic externalities to development. Include more systematic use of pricing mechanisms to influence the location and nature of development such as financial contributions, road user charges, congestion tolls and parking fees, accompanied by improvements in public transit services.

- Distribute the cost of infrastructure more evenly by complementing development contributions with higher user fees levied on those benefiting from the services provided. 


\section{Bibliography}

ANZ (2007), Survey of Property Investment, 2007.

ANZ (2008), Survey of Property Investment, 2008.

ANZ (2009), Survey of Property Investment, 2009.

ANZ (2010), Survey of Property Investment, 2010.

Andrews, D., A.C. Sánchez and A. Johansson (2011), "Housing Markets and Structural Policies in OECD Countries", OECD Economics Department Working Paper, No. 836, OECD Publishing, Paris.

ARC (2007), "Growing Smarter: An Evaluation of the Auckland Regional Growth Strategy", Auckland Regional Council.

Barker, K. (2008), "Planning policy, planning practice, and housing supply", Oxford Review of Economic Policy, 24(1), 34-49.

Bollard, A., B. Hodgetts, P. Briggs and M. Smith (2006), "Household Savings and Wealth in New Zealand", Reserve Bank of New Zealand, Wellington.

Briggs, P. (2007), "Lessons from the Economics Department's work on household balance sheets and related issues", Reserve Bank of New Zealand, Bulletin, 70, No. 4.

Brooks, M.R. and R. Cubero (2009), "New Zealand Bank Vulnerabilities in International Perspective", IMF Working Paper No. 09/224.

Brueckner, J.K. (2007), "Urban growth boundaries: An effective second-best remedy for unpriced traffic congestion", Journal of Housing Economics, 16, 263-73.

Building and Construction Sector Productivity Taskforce (2009), "A Modern Efficient and Productive New Zealand Build Infrastructure Industry", Report of the Building and Construction Sector Productivity Taskforce.

Burman, L.E. and D. White (2003), "Taxing Capital Gains in New Zealand”, New Zealand Journal of Taxation Law and Policy, pp. 355-86.

Case, K.E. and R.J. Shiller (1989), "The Efficiency of the Market for Single-Family Homes" American Economic Review, 79(1), 125-37.

Chen, D. and J. Mintz (2009), "Capital Taxation in New Zealand: A Review from an International Perspective”, Background paper prepared for the Tax Working Group, session 4, available at: http://www.victoria.ac.nz/sacl/cagtr/twg/session-four.aspx 
CMD Task Force (2009), “Capital Markets Matter”, Summary Report of the Capital Market Development Task Force.

Coleman, A. (2009), "The long-term effects of capital gains taxes in New Zealand", Motu Working Paper, 09-13.

Coleman, A. and A. Grimes (2009), "Fiscal, Distributional and Efficiency Impacts of Land and Property Taxes", Motu Working Paper, 09-14.

Coulson, N.E. (2002), "Housing Policy and the Social Benefits of Homeownership”, Federal Reserve Bank of Philadelphia Business Review, 2002 Second Quarter.

Deloitte (2010), "New Zealand reverse mortgage study grows to total loans of $\$ 447 \mathrm{~m}$ at 31 December 2009", http://www.deloitte.com.

DEMHOW (2010), "Releasing Housing Equity”, Demographic Change and Housing Wealth Briefing 3, February, www.demhow.bham.ac.uk.

DiPasquale, D. and E. Glaeser (1999), "Incentives and Social Capital: Are Homeowners Better Citizens?" Journal of Urban Economics, 45, 354-84.

Doling, J. and R. Ronald (2010), "Property-based welfare and European homeowners: how would housing perform as a pension?", Journal of Housing and the Built Environment, 25(2), 227-41.

DTZ New Zealand (2004), "Changes in the Structure of the New Zealand Housing Market", Report prepared for the Centre for Housing Research, New Zealand.

DTZ New Zealand (2008), "The Intermediate Housing Market in New Zealand”, Report prepared for the Centre for Housing Research, New Zealand, December.

Fairgray, D. (2009), "Land and Housing Supply", Paper presented at the CHRANZ Housing Workshop "After the Boom - Where to From Here?", 9 July.

Foresight (2010), "Land Use Futures: Making the most of land in the $21^{\text {st }}$ century", Foresight Land Use Futures Project Final Project Report, UK Government Office for Science.

Fraser, P., M. Hoesli, and L. McAlevey (2008), "House Prices and Bubbles in New Zealand”, Journal of Real Estate Finance and Economics, 37, 71-91.

Frick, J.R. and M.M. Grabka (2003), "Imputed Rent and Income Inequality: A Decomposition Analysis for Great Britain, West Germany and the U.S.”, Review of Income and Wealth 49, 513-37.

Girouard, N., M. Kennedy, P. van den Noord and C. André (2006), "Recent House Price Developments: The Role of Fundamentals", OECD Economics Department Working Paper, No. 475, OECD Publishing, Paris.

Green, R. and M. White (1997), "Measuring the Benefits of Homeowning: Effects on Children", Journal of Urban Economics, 441-61.

Grimes, A. and A. Aitken (2006), "Regional Housing Markets in New Zealand: House Price, Sales and Supply Responses", Report prepared for the Centre for Housing Research and Housing New Zealand Corporation. 
Grimes, A. and Y. Liang (2007), "Spatial Determinants of Land Prices in Auckland: Does the Metropolitan Urban Limit Have an Effect?", Motu Working Paper 07-09.

Grimes, A., A. Aitken, I. Mitchell and V. Smith (2006), "Housing Supply in the Auckland Region 2000-2005”, Motu Working Paper, December.

Grimes, A., M. Holmes and N. Tarrant (2010), "New Zealand Housing Markets: Just a Bit-Player in the A-League?", Motu Working Paper 10-07.

Hargreaves, D. (2008), “The tax system and housing demand in New Zealand”, Reserve Bank of New Zealand Discussion Paper Series, DP2008/06.

Hill, G. (2008), "The Effectiveness of the Auckland Metropolitan Urban Limit - Ring-fencing Urban Development", Paper presented at the Environmental Defence Society Conference, 11-12 June.

Housing New Zealand Corporation (2010), Statement of Intent 2010-2013.

HSA Group (2010), “Home and Housed: A Vision for Social Housing in New Zealand”, Housing Shareholders Advisory Group, April.

IBFD (2009), Global individual tax handbook, 2009, International Bureau of Fiscal Documentation, edited by Nick Cowley, Carlos Gutiérrez, Juhani Kesti and Mei-June Soo, IBFD, Amsterdam.

Johansson, A., C. Heady, J. Arnold, B. Brys and L. Vartia (2008), "Taxation and Economic Growth", OECD Economics Department Working Paper, No. 620, OECD Publishing, Paris.

Kamal-Chaoui, L. and A. Robert (2009), "Competitive Cities and Climate Change", OECD Regional Development Working Paper, No. 2.

Kerr, S., A. Aitken and A. Grimes (2004), "Land Taxes and Revenue Needs as Communities Grow and Decline: Evidence from New Zealand”, Motu Working Paper 04-01.

Kida, M. (2009), "Financial vulnerability of mortgage-indebted households in New Zealand - evidence from the Household Economic Survey", RBNZ Bulletin, March.

KPMG (2010), KPMG's Corporate and Indirect Tax Survey 2010.

Le, T., J. Gibson and S. Stillman (2010), "Household Wealth and Saving in New Zealand: Evidence from the Longitudinal Survey of Family, Income and Employment", Motu Working Paper 10-06.

Local Government Rates Inquiry Panel (2007), Funding Local Government: Report of the Local Government Rates Inquiry, www.ratesinquiry.govt.nz

McCluskey, W., A. Grimes, A. Aitken, S. Kerr and J. Timmins (2006), "Rating Systems in New Zealand: An Empirical Investigation into Local Choice", Journal of Real Estate Literature, 14, 381-97.

Ministry for the Environment (2010), "Building Competitive cities: Reform of the urban and infrastructure planning system: A Technical Working Paper”, Wellington, October.

Morrison, P. (2008), “On the falling rate of home ownership in New Zealand”, Centre for Housing Research, Aotearoa New Zealand. 
New Zealand Treasury (2010), "Saving in New Zealand - Issues and Options", Report prepared for the Savings Working Group, September.

van den Noord, P. (2006), "Are House Prices Nearing a Peak? A Probit Analysis for 17 OECD Countries", OECD Economics Department Working Paper, No. 488, OECD Publishing, Paris.

van den Noord, P. and C. Heady (2001), "Surveillance of Tax Policies: A Synthesis of Findings in Economic Surveys", OECD Economics Department Working Papers, No. 303, OECD Publishing, Paris.

NZ Treasury and IRD (2009), "The taxation of capital gains", Background paper for Tax Working Group, Prepared by Inland Revenue Department and the New Zealand Treasury.

OECD (2000a), OECD Economic Surveys: New Zealand, OECD Publishing, Paris.

OECD (2000b), "Disparities in regional labour markets", Chapter 2 of OECD Employment Outlook, pp. 31-78, OECD Publishing, Paris.

OECD (2006), OECD Tax Policy Studies No. 14: Taxation of Capital Gains of Individuals: Policy Considerations and Approaches, OECD Publishing, Paris.

OECD (2010a), OECD Tax Policy Reform and Economic Growth, Tax Policy Studies No. 20, OECD Publishing, Paris.

OECD (2010b), OECD Regional Development Policies in OECD Countries - Annex C, Urban-Rural Linkages: In View of Controlling Urban Sprawl, OECD Publishing, Paris.

Page, I. (2009), "Residential Construction and Costs", Paper for CHRANZ Housing Workshop After the Boom - Where to From Here?, 9 July.

Poterba, J. (1992), “Taxation and Housing: Old Questions, New Answers”, American Economic Review, $82,237-42$.

Quddus, M.A., M.G.H. Bell, J.-D. Schmocker and A. Fonzone (2007), "The impact of the congestion charge on the retail business in London: An econometric analysis", Transport Policy, 14, 433-44.

Sánchez, A.C. and A. Johansson (2011), "The Price Responsiveness of Housing Supply in OECD Countries", OECD Economics Department Working Paper, No. 837, OECD Publishing, Paris.

Scanlon, K. and C. Whitehead (2004), "International Trends in Housing Tenure and Mortgage Finance", Council of Mortgage Lenders.

Scobie, G., T. Le and J. Gibson (2007), "Housing in the Household Portfolio and Implications for Retirement Saving: Some Initial Finding from SOFIE", New Zealand Treasury Working Paper 07/04.

SOLUTIONS (2009), Sustainability of Land Use and Transport in Outer Neighbourhoods, Final Report.

Sun, W., R. K. Triest and A. Webb (2007), "Optimal Retirement Asset Decumulation Strategies: The Impact of Housing Wealth", Federal Reserve Bank of Boston Public Policy Discussion Papers No. 07-2. 
van Suntum, U. (2009), "Housing, Taxation and Retirement Income”, Journal of Housing Economics, 18, 249-55.

Tanzi, V. and H.H. Zee (1998), "Taxation and the Household Saving Rate: Evidence from OECD Countries", IMF Working Paper 98/36.

TWG (2010), “A Tax System for New Zealand's Future”, Report of the Victoria University of Wellington Tax Working Group, January.

Tumbarello, P. and S. Wang (2010), "What Drives House Prices in Australia? A Cross-Country Approach", IMF Working Paper 10/291.

Yates, J. (2000), "Is Australia's home-ownership rate really stable? An examination of change between 1975 and 1994", Urban Studies, 37, 319-42. 


\section{Housing-related taxation: interest deductibility, imputed rent and capital gains tax}

\begin{tabular}{|c|c|c|c|c|c|c|}
\hline & \multirow{2}{*}{$\begin{array}{c}\text { Mortgage interest } \\
\text { deductibility }\end{array}$} & \multirow{2}{*}{$\begin{array}{l}\text { Inheritance/ } \\
\text { Estate Tax }\end{array}$} & \multirow{2}{*}{ Tax on imputed rents } & \multicolumn{3}{|c|}{ Capital gains tax (CGT) } \\
\hline & & & & Primary residence & Other residence & Other assets \\
\hline Australia & No & No & No & No & $\begin{array}{l}\text { Yes, on } 50 \% \text { of the capital gain at marginal tax } \\
\text { rate if held for } 1 \text { year or more. Otherwise taxed } \\
\text { on full capital gain. }\end{array}$ & $\begin{array}{l}\text { Taxed on } 50 \% \text { of gains at marginal tax rate } \\
\text { if held for } 1 \text { year or more. Otherwise taxed } \\
\text { on full capital gain. }\end{array}$ \\
\hline Austria & Yes. & No & No & $\begin{array}{l}\text { Taxed at marginal tax rate, exempt after } \\
2 \text { years holding. }\end{array}$ & $\begin{array}{l}\text { Taxed at marginal income tax rate, exempt after } \\
10 \text { years holding. }\end{array}$ & $\begin{array}{l}\text { Taxed on speculative gains at half of } \\
\text { marginal income tax rate, otherwise } \\
\text { exempt. }\end{array}$ \\
\hline Belgium & Yes. & Yes & $\begin{array}{l}\text { Subject to immovable } \\
\text { withholding tax but not to } \\
\text { income tax. }\end{array}$ & No & $\begin{array}{l}\text { Taxed at } 16.5 \% \text { if held less than } 5 \text { years, } \\
\text { exempt after } 5 \text { years holding. Taxed at } 33 \% \text { on } \\
\text { speculative gains. }\end{array}$ & $\begin{array}{l}\text { Taxed on speculative gains at } 33 \% \text { rate, } \\
\text { otherwise exempt. }\end{array}$ \\
\hline Canada & No & No & No & No & $\begin{array}{l}\text { Taxed on } 50 \% \text { of the capital gain at marginal } \\
\text { income tax rate. }\end{array}$ & $\begin{array}{l}\text { Taxed on } 50 \% \text { of gains at marginal income } \\
\text { tax rate. }\end{array}$ \\
\hline Czech Republic & Yes. & Yes & No & $\begin{array}{l}\text { Taxed at } 15 \% \text { rate, exempt after } 2 \text { years } \\
\text { holding or if proceeds reinvested in } \\
\text { another residence. }\end{array}$ & Taxed at $15 \%$, exempt after 5 years holding. & Taxed at $15 \%$ flat rate. \\
\hline Denmark & Yes. & Yes & No & No & Taxable as capital income & $\begin{array}{l}\text { Taxed at } 28 \% \text { rate below DKK } 48300 \\
\text { and } 42 \% \text { otherwise. }\end{array}$ \\
\hline Estonia & Yes & & No & Exempt. & Exempt if held more than 2 years. & Taxed at $2 \%$ flat rate. \\
\hline Finland & Yes & Yes & No & $\begin{array}{l}\text { Taxed at flat rate of } 28 \% \text {, exempt after } \\
2 \text { years holding. }\end{array}$ & Taxed at $28 \%$ flat rate. & Taxed at $28 \%$ flat rate. \\
\hline France & No from 2011. & Yes & No & No & $\begin{array}{l}\text { Taxed at } 16 \% \text { flat rate, exempt after } 15 \text { years } \\
\text { holding. }\end{array}$ & Taxed at flat rate of $18 \%$. \\
\hline Germany & No & Yes & No & $\begin{array}{l}\text { From 2010: taxed at income tax rate, } \\
\text { exempt after } 10 \text { years holding. }\end{array}$ & $\begin{array}{l}\text { From 2010: Taxed at marginal income tax rate, } \\
\text { exempt after } 10 \text { years holding. }\end{array}$ & $\begin{array}{l}\text { From 2010: Taxed at marginal income tax } \\
\text { rate, exempt after } 1 \text { year holding. }\end{array}$ \\
\hline Greece & Yes. & Yes & $\begin{array}{l}\text { Yes on principal dwellings } \\
\text { larger than of } 200 \mathrm{~m} 2 \text { and } \\
\text { on second house larger } \\
\text { than } 150 \mathrm{~m} 2 \text {. }\end{array}$ & No & From 2010: Taxed at $5-20 \%$ rate. & From 2010 , taxed at $10 \%$ flat rate. \\
\hline Hungary & No & Yes & No & $\begin{array}{l}\text { Taxed at } 25 \% \text { flat rate, exempt after } 5 \\
\text { years holding. }\end{array}$ & $\begin{array}{l}\text { Taxed at } 25 \% \text { flat rate, exempt after } 5 \text { years } \\
\text { holding. }\end{array}$ & Taxed at $25 \%$ flat rate. \\
\hline Iceland & Yes & Yes & $\begin{array}{l}\text { Yes. } 70 \% \text { of rent taxed } \\
\text { at } 15 \% .\end{array}$ & $\begin{array}{l}\text { Taxed at } 18 \% \text { rate, exempt after } 2 \text { years } \\
\text { holding or if proceeds reinvested in } \\
\text { another residence. }\end{array}$ & From 2010: Taxed at $18 \%$ rate. & From 2010: Taxed at $18 \%$ rate. \\
\hline Ireland & Yes. & Yes & No & $\begin{array}{l}\text { Exempt, but the increases in value due to } \\
\text { improvements are taxable. }\end{array}$ & From April 2009: Taxed at $25 \%$ rate. & $\begin{array}{l}\text { From April 2009: Taxed at } 25 \% \text { rate. First } \\
\text { EUR } 1270 \text { of gains exempt. }\end{array}$ \\
\hline Israel & No & - & No & No & - & $\begin{array}{l}\text { Taxed at } 20 \% \text {. For significant shareholders } \\
\text { taxed at } 25 \% \text {. }\end{array}$ \\
\hline
\end{tabular}


Annex. Housing-related taxation: interest deductibility, imputed rent and capital gains tax (continued)

\begin{tabular}{|c|c|c|c|c|c|c|}
\hline & \multirow{2}{*}{$\begin{array}{l}\text { Mortgage interest } \\
\text { deductibility }\end{array}$} & \multirow{2}{*}{$\begin{array}{l}\text { Inheritance/ } \\
\text { Estate Tax }\end{array}$} & \multirow{2}{*}{ Tax on imputed rents } & \multicolumn{3}{|c|}{ Capital gains tax (CGT) } \\
\hline & & & & Primary residence & Other residence & Other assets \\
\hline Italy & Yes. & Yes & Exempt for principal dwellings. & No & $\begin{array}{l}\text { Taxed at either flat rate of } 20 \% \text { or } \\
\text { marginal income tax rate, exempt } \\
\text { after } 5 \text { years holding. }\end{array}$ & $\begin{array}{l}\text { Taxed on } 49.72 \% \text { of gains at } \\
\text { marginal income tax rate. }\end{array}$ \\
\hline Japan & No & Yes & No & $\begin{array}{l}\text { Taxed at } 30 \% \text { rate up to } 5 \text { years holding, and } \\
\text { at } 15 \% \text { rate after } 5 \text { years holding. }\end{array}$ & $\begin{array}{l}\text { Taxed at } 20 \% \text { after } 5 \text { years holding, } \\
\text { otherwise taxed at } 39 \% \text {. }\end{array}$ & Taxed at $15 \%$ rate. \\
\hline Korea & No & Yes & No & Taxed at $6-35 \%$, exempt after 3 years holding. & $\begin{array}{l}\text { Taxed at } 6-35 \% \text { rate depending on } \\
\text { the amount. }\end{array}$ & Taxed at $6-35 \%$ rate. \\
\hline Luxembourg & Yes. & Yes & $\begin{array}{l}\text { Yes. Imputed rent at } 4-6 \% \text { of unit } \\
\text { value of the dwelling based on } \\
\text { valuation on } 1 \text { January } 1941 .\end{array}$ & $\begin{array}{l}\text { Taxed at marginal income tax rate, exempt } \\
\text { after } 2 \text { years holding. }\end{array}$ & $\begin{array}{l}\text { Taxed at maximum rate of } 19.475 \% \text {, } \\
\text { or at marginal income tax rate for less } \\
\text { than } 5 \text { years holding. }\end{array}$ & $\begin{array}{l}\text { Taxed at maximum rate of } 19.475 \% \\
\text { or at marginal income tax rate for } \\
\text { less than } 6 \text { months holding. }\end{array}$ \\
\hline Mexico & No & No & - & $\begin{array}{l}\text { Taxed at marginal tax rates up to } 2 \text { years } \\
\text { holding, exempt otherwise. }\end{array}$ & Taxed at marginal tax rates. & $\begin{array}{l}\text { Exempt for securities classified as } \\
\text { available to the public. }\end{array}$ \\
\hline Netherlands & Yes & Yes & $\begin{array}{l}\text { Yes. Imputed rent of up to } 0.55 \% \text { of } \\
\text { market value of the dwelling. }\end{array}$ & No & No & No \\
\hline New Zealand & No & No & No & No & No & No \\
\hline Norway & Yes. & Yes & No & $\begin{array}{l}\text { Exempt if the owner has occupied the house } \\
\text { in } 12 \text { out of the last } 24 \text { months. }\end{array}$ & Taxed at $28 \%$ rate. & Taxed at $28 \%$ rate. \\
\hline Poland & No & Yes & $\begin{array}{l}\text { Yes. Taxed according to a } \\
\text { progressive scale or taxed by lump } \\
\text { sum at } 8.5 \%+20 \% \text { of excess over } \\
€ 4000 .\end{array}$ & $\begin{array}{l}\text { Taxed at } 19 \% \text { rate, exempt after } 5 \text { years } \\
\text { holding or within } 2 \text { years if proceeds reinvested } \\
\text { in another principal dwelling or to pay mortgage } \\
\text { loan. }\end{array}$ & $\begin{array}{l}\text { Taxed at } 19 \% \text { flat rate, exempt after } 5 \\
\text { years holding. }\end{array}$ & Taxed at $19 \%$ flat rate. \\
\hline Portugal & Yes & No & No & $\begin{array}{l}\text { Taxed on } 50 \% \text { of gains at marginal income tax } \\
\text { rate, exempt if proceeds reinvested in another } \\
\text { principal residence within } 2 \text { years. }\end{array}$ & $\begin{array}{l}\text { Taxed on } 50 \% \text { of gains at marginal } \\
\text { income tax rate. }\end{array}$ & $\begin{array}{l}\text { Taxed at } 10 \% \text { rate or at marginal } \\
\text { income tax rate. }\end{array}$ \\
\hline Slovak Republic & No & No & No & $\begin{array}{l}\text { Taxed at } 19 \% \text { rate, exempt after } 2 \text { years } \\
\text { holding. }\end{array}$ & $\begin{array}{l}\text { Taxed at } 19 \% \text { rate, exempt after } \\
5 \text { years holding. }\end{array}$ & $\begin{array}{l}\text { Taxed at } 19 \% \text { rate, exempt up to a } \\
\text { ceiling. }\end{array}$ \\
\hline Slovenia & No & - & Yes & Exempt after 3 years holding period. & - & \\
\hline Spain & Yes & Yes & No, on principal dwellings. & $\begin{array}{l}\text { Exempt if reinvested in another principal } \\
\text { residence or for Individuals over age } 65 .\end{array}$ & Taxed at marginal income tax rate & Taxed at marginal income tax rate \\
\hline Sweden & Yes & No & No & $\begin{array}{l}\text { Taxed at } 22 \% \text { rate, but may be deferred if } \\
\text { reinvested in principal residence. }\end{array}$ & $\begin{array}{l}\text { Taxed on } 22 / 30^{\text {th }} \text { of gains at } 30 \% \text { flat } \\
\text { rate. }\end{array}$ & Taxed at $30 \%$ flat rate. \\
\hline Switzerland & Yes & Yes & Yes & Yes & Yes & Yes \\
\hline Turkey & No & Yes & Yes & Exempt & $\begin{array}{l}\text { Taxed at marginal income tax rate, } \\
\text { exempt after } 5 \text { years holding. }\end{array}$ & $\begin{array}{l}\text { Taxed at marginal income tax rate, } \\
\text { exempt for shares in resident } \\
\text { companies held for } 3-12 \text { months. }\end{array}$ \\
\hline United Kingdom & No & Yes & No & Exempt & From 2008/09: Taxed at $18 \%$ rate. & From 2008/09: Taxed at $18 \%$ rate. \\
\hline United States & Yes. & Yes & No & $\begin{array}{l}\text { First } \$ 250 \mathrm{~K}(\$ 500 \mathrm{~K} \text { if married) excluded if } \\
\text { dwelling occupied } 2 \text { years over } 5 \text { year period. }\end{array}$ & Yes & Yes \\
\hline
\end{tabular}

Source: OECD Housing Market Questionnaire, European Tax Handbook (2009), The International Comparative Legal Guide to Real Estate 2010. 


\section{WORKING PAPERS}

The full series of Economics Department Working Papers can be consulted at www.oecd.org/eco/working_papers/

877. The sharing of macroeconomic risk: Who loses (and gains) from macroeconomic shocks (July 2011) by Rudiger Ahrend, Jens Arnold and Charlotte Moeser

876. Estonia: making the most of globalisation (June 2011) Robert Price and Andreas Wörgötter

875. The effects of downturns on labour force participation: evidence and causes (June 2011) Romain Duval, Mehmet Eris and Davide Furceri

874 A dynamic factor model for world trade growth (June 2011) Stéphanie Guichard and Elena Rusticelli

873. Towards a better understanding of the informal economy (May 2011) Dan Andrews, Aida Caldera Sánchez and Åsa Johansson

872. Tax competition between sub-central governments (May 2011) Hansjörg Blöchliger and José-Maria Pinero-Campos

871. The growth effects of current account reversals: the role of macroeconomic policies (May 2011) Luiz de Mello, Pier Carlo Padoan and Linda Rousová

870. Les politiques du logement en France (May 2011) Bénédicte Rolland

869. How important is wealth for explaining household consumption over the recent crisis? An empirical study for the United States, Japan and the euro area

(May 2011) Clovis Kerdrain

868. Adjusting fiscal balances for asset price cycles (May 2011) Robert Price and Thai-Thanh Dang

867. Improving the functioning of the housing market in the United Kingdom (May 2011) Christophe André

866. An analysis of demand for foreign exchange reserves (May 2011) Peter Vujanovic

865. Episodes of large capital inflows and the likelihood of banking and currency crises and sudden stops

(May 2011) Davide Furceri, Stephanie Guichard and Elena Rusticelli

864. The effect of episodes of large capital inflows on domestic credit (May 2011) Davide Furceri, Stephanie Guichard and Elena Rusticelli

863. Medium-term determinants of international investment positions: the role of structural policies (May 2011) Davide Furceri, Stephanie Guichard and Elena Rusticelli 
862. French social housing in an international context

(May 2011) Kathleen Scanlon and Christine Whitehead

861. Making the French housing market work better (May 2011) by Hervé Boulhol

860. Surveillance by international institutions: lessons from the global financial and economic crisis (April 2011) by Kumiharu Shigehara and Paul Atkinson

859. France's environmental policies: internalising global and local externalities (April 2011) by Balázs Égert

858. Bringing French public debt down: the options for fiscal consolidation (April 2011) by Balázs Égert

857. Policy frameworks in the post-crisis environment (April 2011) by Nigel Pain and Oliver Röhn

856. Global imbalances, exchange rate pegs and capital flows: a closer look (April 2011) by Paul van den Noord

855 Interest rate pass-through during the global financial crisis: the case of Sweden (April 2011) by Niels-Jakob Harbo Hansen and Peter Welz

854 What drives inflation in the major OECD Economies (April 2011) by Diego Moccero, Shingo Watanabe and Boris Cournède

853 Mitigation potential of removing fossil fuel subsidies: A general equilibrium assessment (April 2011) by J.M. Burniaux and J. Chateau

852 Enhancing labour utilisation in a socially inclusive society in Australia (April 2011) by Vassiliki Koutsogeorgopoulou

851 Meeting infrastructure needs in Australia (March 2011) by Claude Giorno

850 Restoring fiscal sustainability in Spain

(March 2011) by Pierre Beynet, Andrés Fuentes, Robert Gillingham and Robert Hagemann

849. Drivers of homeownership rates in selected OECD countries (March 2011) by Dan Andrews and Aida Caldera Sánchez

848. How efficient are banks in Hungary?

(February 2011) by Margit Molnár and Dániel Holló

847. Strengthening the macroeconomic policy framework in South Africa (February 2011) by Tatiana Lysenko and Geoff Barnard

846. To move or not to move: what drives residential mobility rates in the OECD? (February 2011) by Aida Caldera Sánchez and Dan Andrews 